\section{Pacific Northwest} National Laboratory

Operated by Battelle for the

U.S. Department of Energy

\title{
Sustainable Building Rating Systems Summary
}

K.M. Fowler

E.M. Rauch

July 2006

Completed by the Pacific Northwest National Laboratory, operated for the U.S. Department of Energy by Battelle.

Completed for the General Services Administration under Contract DE-AC05-76RL061830. 


\title{
DISCLAIMER
}

This report was prepared as an account of work sponsored by an agency of the United States Government. Neither the United States Government nor any agency thereof, not Battelle Memorial Institute, nor any of their employees, makes any warranty, expressed or implied, or assumes any legal liability or responsibility for the accuracy, completeness, or usefulness of any information, apparatus, product, or process disclosed, or represents that its use would not infringe privately owned rights. Reference herein to any specific commercial product, process, or service by trade name, trademark, manufacturer, or otherwise does not necessarily constitute or imply its endorsement, recommendation, or favoring by the United States Government or any agency thereof, or Battelle Memorial Institute. The views and opinions of authors expressed herein do not necessarily state or reflect those of the United States Government or any agency thereof.

\author{
PACIFIC NORTHWEST NATIONAL LABORATORY \\ operated by \\ BATTELLE \\ for the \\ UNITED STATES DEPARTMENT OF ENERGY \\ under Contract DE-AEC05-76RL01830
}




\section{Executive Summary}

The market place of the design and construction of high performance buildings is dynamic and evolving. Professionals through out the building industry use assessment rating systems to evaluate and differentiate their product or design. GSA is a significant participant in the building industry and it is critical for GSA to evaluate the performance of projects. Since 2003, all GSA projects are to use and achieve a certified rating from the U.S. Green Building Council's Leadership in Enviromental and Energy Design $\left(\mathrm{LEED}^{\circledR}\right)$ green building rating system. In order to keep pace with the evolving and developing rating systems available, Section 609 of the Transportation, Treasury, Housing and Urban Development, the Judiciary, the District of Columbia, and Independent Agencies Appropriations Act, 2006 (PL109-115, signed November 30, 2005), states: "... the Administrator shall report to the relevant congressional committees of jurisdiction on the progress and next steps toward recognition of other credible sustainable building rating systems within the U.S. General Services Administration (GSA) sustainable building procurement process." This summary document was prepared to offer information on sustainable building rating systems for GSA's consideration in their response to this request. This document does not provide a recommendation for GSA but rather a summary of the information found for each sustainable building rating system.

GSA buildings are typically built for a 100 year life following stringent guidelines to enhance the asset value. GSA's Design Excellence program compels design teams to create the highest quality buildings. It is commonly recognized that a whole building, integrated design approach upholds a sustainable or green building design, which in turn provides the optimal performance for the desired design goals. Sustainable design tools used for GSA projects must set parameters to improve quality, decrease the life cycle environmental impact, and optimize life cycle costs of the buildings. The tools must support long-term performance for an innovative and flexible future. GSA must evaluate its buildings consistently using one system in order that the projects can be compared equally with other GSA buildings, other Federal buildings, and the U.S. building market. Using one sustainable building rating system allows for comparisons and benchmarking of existing buildings as well as a mechanism to track GSA's progress toward designing and operating the best buildings for their occupants.

The information compiled in this document was collected from January 15 - May 1, 2006 through literature reviews and internet available information. Information was also provided directly from the rating system owners. Sustainable building rating systems evolve, therefore a time frame was used to create absolute boundaries. The rating systems change frequently to adjust to the market which makes capturing the current state behind the scenes a challenge. Although publicly available information and rating system provided information do not tell "the whole story", this is documentable information for the rating system selection process. Additionally, there are green building experts that can offer anecdotal information on their experience with these rating systems. This type of information was not solicited or included due to the challenge of ensuring a balanced and currently accurate review. 
This summary is organized in sections which sequentially collect, narrow and filter the building rating system information to those which would be fitting for GSA's business objectives. Section I positions the purpose of the document. Section II lists the numerous systems that were found during the search for whole building analysis tools. This search identified many tools that were not applicable to the review but known in the buildings' industry. Appendix B lists these tools for reference. Additionally, in Section II, the list of building rating systems is shortened by combining rating systems with multiple country applications or systems that were tailored from other applications. Next, Section III outlines the screening criteria used to narrow down the review to rating systems that would be potentially usable to GSA. Section IV further narrows the summary by defining the GSA drivers for sustainable design and rating systems which were used to develop review criteria. Section V specifically defines the review criteria to filter each rating system's features. Section VI provides summary descriptions of each rating system which advanced through the screening analysis. Subsequently, Section VII presents the quantifiable and comparable information for the five selected sustainable building rating systems. Finally, the document summary in Section VIII provides a brief highlight of the information found for each of the selected rating systems but, as noted above, does not offer recommendations.

The review criteria of were defined to address GSA drivers for sustainable design and the use of a rating system. The Federal drivers include:

- Federal Leadership in High Performance and Sustainable Buildings Memorandum of Understanding (January 2006)

- Energy Policy Act of 2005 (July 2005), Public Law 109-58

- Office of Management and Budget Circular No. A-11, Section 55, "Energy and Transportation Efficiency Management" (2002)

- Executive Order 13123, "Greening the Government through Efficient Energy Management" (June 1999)

- Executive Order 13101, "Greening the Government through Waste Prevention, Recycling, and Federal Acquisition" (September 1998)

The criteria include the applicability to GSA project and building types, the system maturity and dependability, and the ability to clearly communicate the rating system results of various building types to multiple audiences. This review does not investigate the details of the technical basis and assumptions behind the rating systems. It does not compare the rating systems score to measured performance, nor does it consider the broader sustainability impact. It does not investigate the supporters or developers of the rating systems. It does not address the fact that the rating systems reflect the values and priorities of their developers and countries. It is understood that these are important considerations when selecting a sustainable building rating system; however the information included in this review was limited to address the current request of Section 609 of the Appropriations Act only.

The five rating systems which progressed through the screening criteria were:

- BREEAM (Building Research Establishment's Environmental Assessment Method) 
- CASBEE (Comprehensive Assessment System for Building Environmental Efficiency)

- GBTool

- Green Globes ${ }^{\mathrm{TM}}$ U.S.

- LEED $^{\circledR}$ (Leadership in Energy and Environmental Design)

These rating systems require varying levels of specialized sustainable design knowledge to be effectively used. A brief summary of the information provided in the document for each rating system includes:

- BREEAM has a long track record in the United Kingdom, but it is not extensively used in the U.S. and it is difficult to obtain current information about the system. Based on the information available, it would not be applicable to all of the GSA project types, specifically tenant build-out for leases. BREEAM is updated annually; however, the current version is not publicly available for purchase and must be acquired through a licensed assessor. The licensed assessor organization determines the BREEAM rating based on quantifiable sustainable design achievements. Although most in the sustainable design profession are aware of BREEAM and many rating systems have used it as their development basis, the rating system results are neither used nor recognized by U.S. design professionals.

- CASBEE is a relatively new system developed for the Japanese market that is available in English, but has not been tested in the U.S. However, CASBEE is potentially applicable in the U.S. market and offers the unique "BEE approach" to representing the performance evaluation data. Based on the information available, it would not be applicable to all of the GSA project types, specifically tenant build-out. The system requires documentation of quantifiable sustainable design achievements which are assessed by trained, first-class architects, which have passed the CASBEE assessor examination. Major modifications are expected to be made to the system every year; however the process for those revisions is unknown. Fewer than 10 buildings have used the system and all of those are in Japan, thus it is relatively unknown in the U.S. market.

- GBTool is an international system that has been used to evaluate U.S. buildings for the Green Building Challenge, including one GSA building. With respect to applicability to GSA project types, GBTool would be applicable for all but tenant build out and operations and maintenance applications; however, an operations and maintenance version is under development. A third party team establishes the qualitative and quantitative measures that are used to evaluate sustainable design achievements and expected building performance. The system has undergone 4 updates since its inception in 1998, which occur based on the experiences gained through its use. Due to the flexibility inherent in the application of GBTool, it tends to require greater technical expertise to implement than other rating systems, which has limited its exposure in the U.S. market. 
- Green Globes ${ }^{\mathrm{TM}}$ US was adapted from Green Globes Canada in 2004 and is the newest system considered in this review. Currently, the U.S. version is not available for all of the GSA project types; however, Green Globes ${ }^{\mathrm{TM}} \mathrm{US}$ is developing tools that address the major renovation, tenant build-out, and operations and maintenance applications. The Green Building Initiative received accreditation as a standards developer by ANSI and is working toward developing Green Globes ${ }^{\mathrm{TM}}$ US as an official ANSI standard. Currently, sustainable design and construction information is submitted on-line for thirdparty verification, which is provided by a Green Building Initiative-approved and Green Globes trained professional. According to feedback provided by the Green Building Initiative, 6 regional assessors were expected to be trained by June 2006. Following the completion of the ANSI process, it is expected the third party verification process will be revised. The Green Globes ${ }^{\text {TM }}$ US rating system was not consistently available on-line during the review period and the current version of the on-line rating system tool is still not available and no date is given for its expected completion. Although there has been much publicity around Green Globes ${ }^{\mathrm{TM}}$ US in recent years, according to feedback provided by the Green Building Initiative, 4 buildings have received Green Globes ratings and 63 buildings have registered, which means they may potentially pursue verification in the future.

- $\quad$ LEED $^{\circledR}$ is currently the dominant system in the United States market and is being adapted to multiple markets worldwide. The currently available LEED ${ }^{\circledR}$ rating systems address all of the GSA building and project types. A Product Development and Maintenance Manual is publicly available which governs how changes are made to the LEED $^{\circledR}$ rating systems. The steps followed for the development of U.S. Green Building Council rating system products include technical development by committee, pilot testing, public comment period, approval by council membership, and then release for public use. For the existing LEED $^{\circledR}$ rating systems, minor updates can occur no more than once a year, while major updates are expected to occur on a 3-5 year cycle, and will follow a defined process including a public comment period. Documentation of the quantifiable sustainable design measures are provided to the U.S. Green Building Council, the developer of the LEED $^{\circledR}$ rating system, for third-party verification. The assessors have been trained and must pass an assessor examination. More than 400 U.S. buildings have received LEED ${ }^{\circledR}$ ratings and more than 3400 buildings are registered and therefore potentially seeking certification. LEED ${ }^{\circledR}$ is not only the U.S. market leader, but is also the most widely use rating system by Federal and state agencies, which makes it easy to communicate a building's sustainable design achievements with others.

GSA will determine which rating system is the most appropriate sustainable building rating system available for evaluation of GSA projects using the following elements:

- A system that is applicable to the large scale and complexity of federal building projects. 
- A stable rating system such that the evaluation of building performance is not subject to drastic change.

- A system which tracks quantifiable achievements in sustainable design and is third party verified by a qualified assessor.

- A system used in the current market with practitioner awareness. 


\section{Table of Contents}

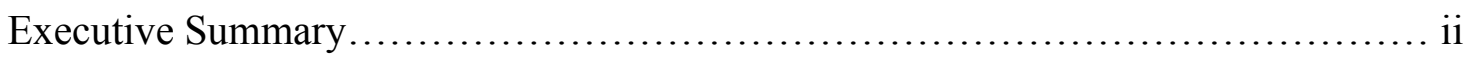

I. Introduction...................................................... 1

II. Sustainable Building Rating Systems...................................

III. Screening Analysis of Rating Systems.................................

IV. GSA Drivers for Sustainable Design and Use of a Rating System.............6

V. Review Criteria for Applicable Rating Systems............................8

VI. Rating System Summaries.............................................. 10

VII. Review of Applicable Rating Systems................................ 18

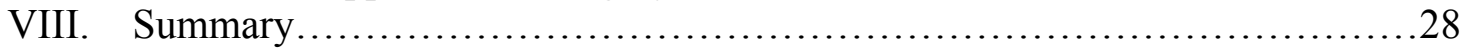

Appendix A $\quad$ References................................................ 31

Appendix B List of Sustainable Design and Operations Related Systems PreScreened from the Analysis..................................................41

Appendix C Additional Rating System Review Data.........................44 


\section{Sustainable Building Rating Systems Summary}

\section{Introduction}

The purpose of this document is to offer information to compare and contrast sustainable building rating systems in response to Section 609 of the Transportation, Treasury, Housing and Urban Development, the Judiciary, the District of Columbia, and Independent Agencies Appropriations Act, 2006 (PL109-115, signed November 30, 2005), which stated: "... the Administrator shall report to the relevant congressional committees of jurisdiction on the progress and next steps toward recognition of other credible sustainable building rating systems within the U.S. General Services Administration (GSA) sustainable building procurement process." This document was prepared to offer information on sustainable building rating systems for GSA's consideration in their response to this request. This review does not:

- provide a recommendation for GSA but rather a summary of the information found for each sustainable building rating system

- investigate the details of the technical basis and assumptions behind the rating systems

- compare rating system scores to measured building performance,

- consider the broader implications of a sustainable society,

- investigate the supporters or developers of the rating systems, or

- address the fact that the rating systems reflect the values and priorities of their developers and countries.

The authors acknowledge that these are important considerations when selecting a sustainable building rating system; however the information included in this review were selected to address the current request.

World-wide there are hundreds of building evaluation tools that focus on different areas of sustainable development and are designed for different types of projects. These tools include life cycle assessment, life cycle costing, energy systems design, performance evaluation, productivity analysis, indoor environmental quality assessments, operations and maintenance optimization, whole building design and operations tools, and more.

For the purposes of this review, 'sustainable building rating systems' are defined as tools that examine the performance or expected performance of a 'whole building' and translate that examination into an overall assessment that allows for comparison against other buildings. For a rating system to add value to the sustainable design and/or operation of a building, it must offer a credible, consistent basis for comparison, evaluate relevant technical aspects of sustainable design, and not be over-burdensome to implement and communicate. In order to identify the most applicable rating systems for GSA projects, the following review approach was used:

1. Identification of sustainable building rating systems

2. Screening analysis of rating systems to limit review to most applicable systems (screening criteria)

3. Identification of GSA drivers for a credible rating system (review criteria)

4. Data collection on applicable rating systems for comparative review 
5. Review of the merits of applicable rating systems as they apply to the GSA procurement processes

Federal requirements and GSA's values and goals guide their decisions on sustainable design. The Federal regulatory drivers include the Federal Leadership in High Performance and Sustainable Buildings Memorandum of Understanding (January 2006), Energy Policy Act of 2005 (July 2005), Office of Management and Budget Circular No. A-11, Section 55, "Energy and Transportation Efficiency Management" (2002), Public Law 109-58, Executive Order 13123, "Greening the Government through Efficient Energy Management" (June 1999), and Executive Order 13101, "Greening the Government through Waste Prevention, Recycling, and Federal Acquisition" (September 1998). GSA's fiscal year 2006 values and goals include the continued focus on results orientation and maintaining world class workforces and workplaces. GSA is committed to designing, building, and operating high performance, sustainably designed buildings. This is clearly stated in the GSA facilities standards for the public building service and is exemplified by the incorporation of sustainable design strategies throughout the document. A sustainable building rating system is one of the tools that facilitates consistent application of sustainable design principles and serves as a measure of accomplishment.

More than 30 potentially useful whole building tools/systems were identified for this review, however most of them did not meet GSA's basic requirements or were variations of the same systems. Screening criteria were developed to narrow down the list of sustainable building rating systems to those where a more detailed review would offer a useful comparison of tools. Five sustainable building rating systems were examined more thoroughly using review criteria to provide a structure for the comparison between systems.

\section{Sustainable Building Rating Systems}

Literature reviews, internet searches, and a presentation from Greenbuild 2005 coauthored by GSA (Boecker, et al., 2005) were utilized to identify currently marketed sustainable building rating systems (see Appendix A for the list of references used to perform this review). Rating system documentation that was identified and publicly available during the time period of January 15, 2006 through May 1, 2006 was used for this review. As an illustration of the necessity to create time boundaries, during the review time period two of the systems made significant changes to their primary webpages and many features were identified as under development. It is recognized that there are planned updates to various rating systems, however for the purpose of this review only the active attributes were considered. Some systems found in the literature review were immediately determined to be not appropriate and are listed in Appendix B along with the reason they were eliminated from the analysis. Table 1 contains an alphabetical list of whole building assessment tools that were considered at the beginning of this review (column one). Column two offers the known development basis for each of those tools. 


\begin{tabular}{|c|c|}
\hline Table 1. Rating System Source(s) & \\
\hline Sustainable Building Rating Systems & Development Basis \\
\hline $\begin{array}{l}\text { BREEAM (Building Research Establishment's Environmental Assessment } \\
\text { Method) }\end{array}$ & Original \\
\hline BREEAM Canada & BREEAM \\
\hline BREEAM Green Leaf & BREEAM, Green Leaf ${ }^{\mathrm{TM}}$ \\
\hline Calabasas LEED & LEED $^{\circledR}$ \\
\hline $\begin{array}{l}\text { CASBEE (Comprehensive Assessment System for Building Environmental } \\
\text { Efficiency) }\end{array}$ & Original \\
\hline CEPAS (Comprehensive Environmental Performance Assessment Scheme) & LEED $^{\circledR}$, BREEAM, HK-BEAM, IBI \\
\hline Earth Advantage Commercial Buildings (Oregon) & Undisclosed \\
\hline EkoProfile (Norway) & Undisclosed \\
\hline ESCALE & Undisclosed \\
\hline GBTool & Original \\
\hline $\begin{array}{l}\text { GEM (Global Environmental Method) For Existing Buildings (Green Globes) - } \\
\text { UK }\end{array}$ & Green Globes Canada \\
\hline GOBAS (Green Olympic Building Assessment System) & CASBEE, LEED ${ }^{\circledR}$ \\
\hline Green Building Rating System - Korea & BREEAM, LEED $^{\circledR}$, BEPAC \\
\hline Green Globes Canada & BREEAM Green Leaf \\
\hline Green Globes $^{\mathrm{TM}} \mathrm{US}$ & Green Globes Canada \\
\hline Green Leaf Eco-Rating Program & Original \\
\hline Green Star Australia & BREEAM, LEED $^{\circledR}$ \\
\hline HK BEAM (Hong Kong Building Environmental Assessment Method) & BREEAM \\
\hline HQE (High Environmental Quality) & Undisclosed \\
\hline iDP (Integrated Design Process) & Original \\
\hline Labs21 & Original \\
\hline LEED $^{\circledR}$ (Leadership in Energy and Environmental Design) & Original \\
\hline LEED Canada & LEED $^{\circledR}$ \\
\hline LEED India & LEED $^{\circledR}$ \\
\hline LEED Mexico & LEED $^{\circledR}$ \\
\hline MSBG (The State of Minnesota Sustainable Building Guidelines) & $\begin{array}{l}\text { LEED }^{\circledR} \text {, Green Building Challenge } \\
\text { ' } 98 \text {, and BREEAM }\end{array}$ \\
\hline NABERS (National Australian Built Environment Rating System) & Undisclosed \\
\hline PromisE & Undisclosed \\
\hline Protocol ITACA & GBTool \\
\hline SBAT (Sustainable Buildings Assessment Tool) & Original \\
\hline Scottsdale's Green Building Program & Undisclosed \\
\hline SPiRiT (Sustainable Project Rating Tool) & LEED $^{\circledR}$ \\
\hline TERI Green Rating for Integrated Habitat Assessment & Original \\
\hline $\begin{array}{l}\text { TQ Building Assessment System (Total Quality Building Assessment } \\
\text { System) }\end{array}$ & Original \\
\hline
\end{tabular}

Many of the systems listed in column one were created by modifying a single system, or integrating multiple systems. Rating systems that were created using other systems and rating systems that had multiple country applications were merged for the screening analysis. For multiple country applications, if there was a rating system developed for a United States use, that system was selected for comparison. If no U.S. 
system was available, systems from the United Kingdom or Canada were selected for comparison (when available). When these options were not available, the original system was selected for comparison. Systems where the basis was not apparent or where other groupings were not valid were considered separately. The rating systems highlighted in bold are the rating systems that were screened further. References used to research the rating systems identified in this document can be found in Appendix A.

\section{Screening Analysis of Rating Systems}

As each of these rating systems was researched it became evident that many of them did not fit the sustainable building rating system needs of GSA. Therefore screening criteria were identified in order to concentrate the review on the systems that had the greatest potential of addressing GSA needs. The screening criteria include:

- Relevance: Does the rating system provide a "whole building evaluation" rather than an evaluation of an individual design feature?

- Measurable: Does the rating system use measurable characteristics to demonstrate the extent of sustainable design incorporated into the building?

- Applicability: Can the rating system be used on all of the types of commercial buildings that GSA builds or leases (e.g., offices, courthouses, and border stations)?

- Availability: Is the rating system easily adaptable to the U.S. market or currently available for use in the U.S. market?

As mentioned previously, there is also a list of sustainable building related tools that were eliminated prior to the screening analysis provided in Appendix B. For each of the unique sustainable building rating systems identified in Table 2, the screening analysis was performed. The results are shown in Table 2.

\begin{tabular}{|c|l|}
\hline \multicolumn{2}{|c|}{ Key } \\
\hline$\checkmark$ & Does Meet Criterion \\
\hline- & Does Not Meet Criterion \\
\hline (blank) & Information Unknown \\
\hline
\end{tabular}

Table 2. Rating Systems Screening Criteria Scores

\begin{tabular}{|l|c|c|c|c|}
\hline \multicolumn{5}{|c|}{ Table 2. Rating Systems Screening Criteria Scores } \\
\hline Rating System Name & Relevance & Measurable & Applicability & Availability \\
\hline BREEAM & $\checkmark$ & $\checkmark$ & $\checkmark$ & $\checkmark$ \\
\hline CASBEE & $\checkmark$ & $\checkmark$ & $\checkmark$ & $\checkmark$ \\
\hline CEPAS & $\checkmark$ & $\checkmark$ & $\checkmark$ & - \\
\hline $\begin{array}{l}\text { Earth Advantage Commercial } \\
\text { Buildings }\end{array}$ & $\checkmark$ & & & \\
\hline EkoProfile & $\checkmark$ & $\checkmark$ & - & - \\
\hline ESCALE & $\checkmark$ & $\checkmark$ & & - \\
\hline GBTool & $\checkmark$ & $\checkmark$ & $\checkmark$ & $\checkmark$ \\
\hline GOBAS & $\checkmark$ & $\checkmark$ & - & - \\
\hline Green Building Rating System & $\checkmark$ & & - & - \\
\hline
\end{tabular}




\begin{tabular}{|l|c|c|c|c|}
\hline \multicolumn{5}{|c|}{ Table 2. Rating Systems Screening Criteria Scores } \\
\hline Rating System Name & Relevance & Measurable & Applicability & Availability \\
\hline Green Globes $^{\text {TM }}$ US & $\checkmark$ & $\checkmark$ & $\checkmark$ & $\checkmark$ \\
\hline Green Leaf ${ }^{\mathrm{TM}}$ & $\checkmark$ & & - & $\checkmark$ \\
\hline Green Star & $\checkmark$ & $\checkmark$ & - & $\checkmark$ \\
\hline HQE & $\checkmark$ & & $\checkmark$ & - \\
\hline iDP & $\checkmark$ & - & $\checkmark$ & $\checkmark$ \\
\hline Labs21 & $\checkmark$ & $\checkmark$ & - & $\checkmark$ \\
\hline LEED & ( & $\checkmark$ & $\checkmark$ & $\checkmark$ \\
\hline MSBG & $\checkmark$ & & $\checkmark$ & $\checkmark$ \\
\hline NABERS & $\checkmark$ & $\checkmark$ & - & $\checkmark$ \\
\hline PromisE & $\checkmark$ & - & - & - \\
\hline SBAT & $\checkmark$ & $\checkmark$ & - & - \\
\hline Scottsdale's Green Building & & & & \\
Program & $\checkmark$ & $\checkmark$ & $\checkmark$ & - \\
\hline TERI & $\checkmark$ & $\checkmark$ & $\checkmark$ & - \\
\hline TQ Building Assessment System & $\checkmark$ & & $\checkmark$ & - \\
\hline
\end{tabular}

Five sustainable building rating systems scored positively on all of the screening criteria (see Table 3). Each of the systems in Table 3 has been considered more thoroughly using the review criteria defined in Section V.

\begin{tabular}{|l|}
\hline \multicolumn{1}{|c|}{ Table 3. Applicable Rating Systems after Screening Criteria } \\
\hline BREEAM (Building Research Establishment's Environmental Assessment Method) \\
\hline CASBEE (Comprehensive Assessment System for Building Environmental Efficiency) \\
\hline GBTool \\
\hline Green Globes $^{\mathrm{TM}}$ US \\
\hline LEED $^{\mathbb{1}}$ (Leadership in Energy and Environmental Design) \\
\hline
\end{tabular}

Only two of these systems have a U.S. specific version, Green Globes ${ }^{\mathrm{TM}}$ US and LEED $^{\circledR}$. Green Globes ${ }^{\mathrm{TM}}$ US was developed based on Green Globes Canada. The Green Globes ${ }^{\mathrm{TM}}$ US version is being used in the comparison since it has been developed specifically for this market. As for the other systems, BREEAM does not have a U.S. version but has been applied minimally in the U.S.; GBTool can be and has been applied to the U.S. market; and CASBEE is available in English and offers an additional comparison from an international perspective. For the rating systems that did not score positively on all of the screening criteria, many still held innovative approaches that may be of interest to GSA. Some of the systems, such as the Australian Green Star Environmental Rating System are developing modules that will broaden their applicability to GSA in the future, but were not ready for consideration in this review. A summary description of each of the ratings systems in Table 3 can be found in Section VI. A comparison based on the review criteria can be found in Section VII. For purposes of comparing the development and technical content of the 
rating systems, only the "new construction" versions of each rating system were used, unless otherwise noted.

\section{GSA Drivers for Sustainable Design and Use of a Rating System}

In order to establish review criteria for the rating systems that are consistent with GSA's drivers for applying a rating system, Federal regulatory drivers as well as agency and program goals related to the design and operation of sustainable buildings are identified and summarized in this section. Those drivers include:

- Federal Leadership in High Performance and Sustainable Buildings Memorandum of Understanding (January 2006)

- Energy Policy Act of 2005 (July 2005), Public Law 109-58

- Office of Management and Budget Circular No. A-11, Section 55, "Energy and Transportation Efficiency Management" (2002)

- Executive Order 13123, "Greening the Government through Efficient Energy Management" (June 1999)

- Executive Order 13101, "Greening the Government through Waste Prevention, Recycling, and Federal Acquisition" (September 1998)

- GSA Mission, Values, Priorities (Fiscal Year 2006 (FY06))

- GSA Sustainable Design Program Goals (FY06)

Other environmental laws applicable to the GSA include the National Environmental Policy Act (NEPA, 1969), the Clean Air Act (CAA, 1990), the Resource Conservation and Recovery Act (RCRA, 1976), Executive Order 13134 "Developing and Promoting Biobased Products and BioEnergy" (EO13134, 1999), and Executive Order 13148 "Greening the Government through Leadership and Environmental Management" (EO13148, 2000). These laws do not specifically mention sustainable design, but support the Agency's environmental ethic.

In January 2006, a Memorandum of Understanding was signed by 19 Federal agencies, including GSA. It states the Federal government commitment to "designing, locating, constructing, maintaining, and operating its facilities in an energy efficient and sustainable manner that strives to achieve a balance that will realize high standards of living, wider sharing of life's amenities, maximum attainable reuse and recycling of depletable resources, in an economically viable manner, consistent with Department and Agency missions." The use of "life cycle concepts, consensus-based standards, and performance measurement..." is encouraged, when appropriate.

The Energy Policy Act states that if life cycle cost effective, "sustainable design principles are applied to the siting, design, and construction of all new and replacement buildings" (Section 109. Federal Building Performance Standards, page 51) and each building project will "comply with third party certification standards for highperformance, sustainable buildings." The Energy Policy Act also sets the current energy efficiency goals for Federal agencies, previously stated in Executive Order 13123.

The Office of Management and Budget Circular A-11 Section 55 was established to document "funding requested for energy efficiency management as required by 
Executive Order 13123...". In the guidance for completing the table for energy efficiency data it is recommended that a sustainable building rating system be used and it is stated that although sustainable design can be incorporated at no additional cost, if additional costs are incurred, they need to be reported.

Executive Order 13123 Section 403 (d) Sustainable Building Design, GSA and DOD were directed to "develop sustainable design principles [and apply those] principles to the siting, design, and construction of new facilities." Agencies are guided to "optimize life-cycle costs, pollution, and other environmental and energy costs associated with the construction, life-cycle operation, and decommissioning of the facility." The "sustainable design principles" were developed by GSA, DOD, and other Federal agencies and are included in the Sustainable section of the Whole Building Design Guide (WBDG). (WBDG, $1999 \&$ 2006) The sustainable design principles, processes, management practices, and recommendations found on this webpage offer a centralized, objective resource for the comparative review of the rating systems. The principles are used later in the document when the technical content is compared, and include: optimizing site potential, optimizing energy use, protecting and conserving water, using environmentally preferable products, enhancing indoor environmental quality, and optimizing operational and maintenance practices. Also in Section 403 (e), it states that built-to-lease solicitations shall include sustainable design and development principles.

Executive Order 13101, in its section on Acquisition Planning (Section 401), guides material selection for building design projects to address the elimination of virgin material requirements, use of bio-based products, use of recovered materials, reuse of products, life cycle cost, recyclability, and the use of environmentally preferable products.

GSA is committed to designing, building, and operating high performance, sustainably designed buildings. This is clearly stated in the GSA facilities standards for the Public Buildings Service and is exemplified by the incorporation of sustainable design strategies throughout the document. As it applies to sustainable design and development, the GSA FY06 Mission, Values, Priorities state the Agency will have a "results orientation" providing the best value for customer agencies and taxpayers, while operating efficiently and maintaining a world class workplace. The Sustainable Design Program goals address the Agency's strategic goals by:

- Providing tools and guidance applicable to existing buildings to better incorporate sustainable design principles.

- Strengthening sustainable design and development contracting language within the leasing program and support the implementation of green leases.

- Being identified as a trusted sustainable design advisor for new design and construction projects in order to expand the success of GSA projects.

- Assisting with building performance metrics to demonstrate the value of high performance, sustainable buildings.

- Communicating approaches to create world class workplaces using integrated, sustainable design principles. 
- Continuing to be a sustainable design resource to other public entities.

These Federal regulatory and GSA drivers have prompted the need to evaluate building design and operation in a consistent, credible manner which can be documented and communicated clearly to a wide audience. Sustainable building rating systems are the current tool available in the market to meet these needs.

\section{Review Criteria for Applicable Rating Systems}

The screening criteria used in Section III were used to focus the review on a set of potentially applicable sustainable building rating systems (Table 3). The review criteria defined in this section will be used to offer review information for each of the applicable ratings systems. Using the above Federal and GSA drivers for sustainable design, seven sustainable building rating system review criteria were identified (detailed definitions provided in Table 4):

1. Applicability - for a rating system to address Executive Order 13123 guidance, the Energy Policy Act of 2005 and the GSA goals it needs to be usable on all of its project and building types.

2. Development - for the rating system to be aligned with the Memorandum of Understanding, the use of life cycle concepts, consensus-based standards, and performance measurement is encouraged.

3. Usability - for the rating system to be applied effectively for all of the GSA building types and projects, it needs to be relatively simple and practical to use.

4. System Maturity - for the rating system to address the GSA goal of being a trusted advisor on sustainable design projects, the system needs to be dependable, have a proven track record, and be endorsed by respected organizations.

5. Technical Content - for the rating system to address the Memorandum of Understanding, the Energy Policy Act, and Executive Order 13101, the system needs to address the primary areas of sustainable design - siting, energy use, water use, indoor environmental quality, and materials selection.

6. Measurability \& Verification - for the rating system to address the Energy Policy Act guidance to comply with third party certification standards and the GSA goal for assisting with performance metrics, the system needs to have a standardized, verifiable system for documenting sustainable design related performance.

7. Communicability - for the rating system to address the GSA goal of being able to communicate their sustainable design approaches for creating world class workplaces in a corporate reporting style, the results needs to be versatile across building and project types, well-known by outside organizations, and easy to understand.

These criteria also contribute to the credibility of the rating system. It is critical to understand the basis of the rating systems in order to explain it to others and ensure the sustainable design environmental performance goals are being met when desired ratings are achieved. Other credibility considerations for sustainable building rating systems include measurements of environmental impacts, development and ownership by legitimate organizations, and having a proven track record of success. (Cole, 2001) 


\section{Table 4. Review Criteria}

\section{Applicability}

Type of Projects: Rating system can be used on all GSA project types, such as New Construction, Major Renovations, Tenant Build-Out (leases), and Operations \& Maintenance.

Type of Buildings: Rating system can be used on all GSA building types, such as Office Buildings, Courthouses, and Border Stations.

\section{Development}

System Management: Identify the level of involvement in the development, funding, and management of the rating system by Government, Private Industry, Non-Governmental Organizations, and others.

Development Approach: Identify if system was developed using a consensus-based approach, life cycle analysis, expert opinion approach, or other.

Openness of Operations: Ability to gather information on the rating system membership and represented organizations.

Transparency of Rating System: Ability to access relevant information either from the internet or other sources.

\section{Usability}

Cost: Identify the cost of using a system, including cost for use or rating system materials, cost of project registration, fees associated with certification, and time typically needed to complete an application.

Ease of Use: Complexity of the tools and technical knowledge needed to complete rating system process, especially for the optimization of energy use, environmentally preferable products use, and indoor environmental quality enhancement.

Product support: Availability and responsiveness of direct requests for assistance, availability of training, and usability of information available on the website, through case studies, documented inquiries, and frequently asked questions.

\section{System Maturity}

System Age: Identify when the rating system was developed, first used, first available for public use, and when the most recent revision was completed.

Number of Buildings: Identify the number of buildings participating in the rating system and the number of buildings that have completed the process for denotation as a green building.

Stability of system: Identify the processes that allow for full implementation of a rating system, including development, testing, and review process, systems for upgrades, process for modifications, and expected frequency of modifications.

\section{Technical Content}

Relevance to Sustainability: Representative of sustainable design needs of the Federal government as identified in the Whole Building Design Guide.

Thoroughness: Detailed review of how rating system addresses key sustainable design characteristics such as optimizing Energy Use, using Environmentally Preferable Products, and enhancing Indoor Environmental Quality (IEQ).

Measurement comparison: Identify the mechanism used as the baseline for comparison, such as industry benchmark or checklist.

\section{Measurability \& Verification}

Standardization: Established collection procedures exist.

Quantification: Numeric measurements facilitate absolute and relative performance evaluation. Certification/Verification Process: Define system for verifying sustainable design practices for a particular application, including who evaluates the application and at what level of detail do they review the applications.

Documentation: Identify what type of documentation is necessary and at what stages of the project the information is collected.

Verifiable/Defendable: Provide documentation of the actual state of the building with respect to the rating system evaluation; include costs and benefits of using the rating system.

\section{Communicability}

Clarity: Well-defined, easily communicated, and clearly understood among multiple parties.

Versatility: Number of systems that use it as its basis for development or comparison. 


\section{Table 4. Review Criteria}

Comparability: Amenable to normalization for comparisons over varying building types, locations, years, or different sustainable design characteristics.

Results Usability: Usability of rating system documentation for communicating the accomplishments of the building project.

Where available, information on each of these review criteria was collected for the five rating systems being compared in this document.

\section{Rating System Summaries}

Summaries of these five sustainable building rating systems and visual examples of their output are offered in alphabetical order in this section.

\section{BREEAM}

BREEAM (Building Research Establishment's Environmental Assessment Method) was developed in the United Kingdom in 1990 and is the building environmental assessment method with the longest track record. BREEAM covers a range of building types including: offices, homes, industrial units, retail units, and schools. Other building types can be assessed using Bespoke BREEAM ("bespoke" is another word for custom-made). When a building is assessed, points are awarded for each criterion and the points are added for a total score. The overall building performance is awarded a "Pass", "Good", "Very Good" or "Excellent" rating based on the score.

BREEAM major categories of criteria for Design and Procurement include the following:

- Management (commissioning, monitoring, waste recycling, pollution minimization, materials minimization)

- Health \& Wellbeing (adequate ventilation, humidification, lighting, thermal comfort)

- Energy (sub-metering, efficiency and $\mathrm{CO}_{2}$ impact of systems)

- Transport (emissions, alternate transport facilities)

- Water (consumption reduction, metering, leak detection)

- Materials (asbestos mitigation, recycling facilities, reuse of structures, facade or materials, use of crushed aggregate and sustainable timber)

- Land Use (previously used land, use of remediated contaminated land)

- Ecology (land with low ecological value or minimal change in value, maintaining major ecological systems on the land, minimization of biodiversity impacts)

- Pollution (leak detection systems, on-site treatment, local or renewable energy sources, light pollution design, avoid use of ozone depleting and global warming substances)

The figures below show sample reporting and certification pages found on-line for a BREEAM example. References consulted for this review of BREEAM included: AggRegain, 2006a-c; BREEAM, 2006; BRE Ltd., 2006; Cole, 2001; FABER MAUNSELL, 2006; Federation of Master Builders, 1999; Peter \& Somervell, 2004; and LACC, 2005. 


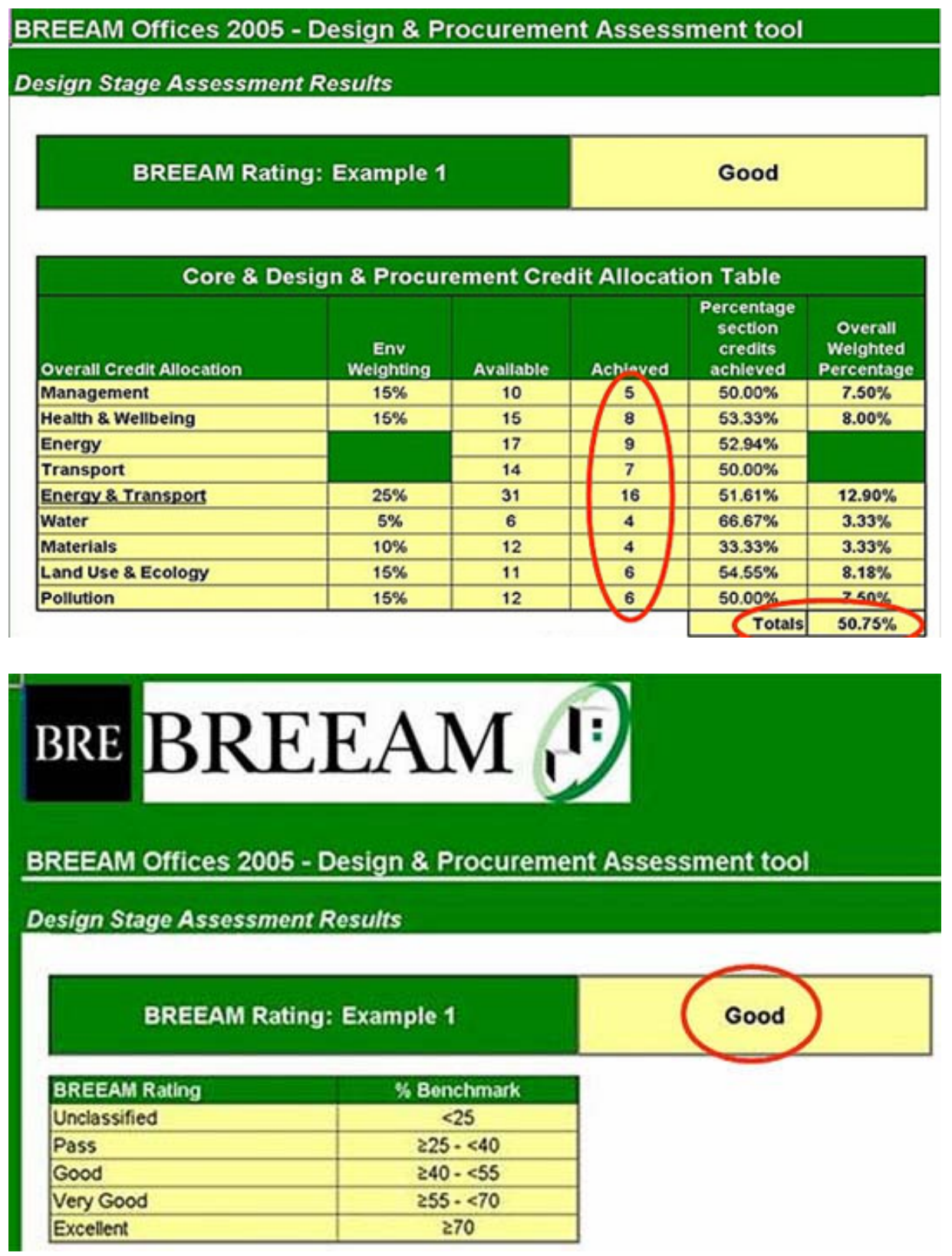

\section{CASBEE}

CASBEE (Comprehensive Assessment System for Building Environmental Efficiency) was developed in Japan, beginning in 2001. The family of assessment tools is based on the building's life cycle: pre-design, new construction, existing buildings, and renovation. CASBEE presents a new concept for assessment that distinguishes environmental load from quality of building performance. By relating these two factors, CASBEE results are presented as a measure of eco-efficiency or BEE (Building Environmental Efficiency). Results are plotted on a graph, with environmental load on one axis and quality on the other - the best buildings will fall in the section representing lowest environmental load and highest quality. Each criterion is scored from level 1 to level 5, with level 1 defined as meeting minimum requirements, level 3 
defined as meeting typical technical and social levels at the time of the assessment, and level 5 representing a high level of achievement. The CASBEE Technical Manual presents detailed definitions of each level for each criterion and includes reference material and calculation tools where needed.

CASBEE major categories of criteria include the following:

Building Environmental Quality and Performance

- Indoor environment (noise and acoustics, thermal comfort, lighting and illumination, and air quality)

- Quality of services (functionality and usability, amenities, durability and reliability, flexibility and adaptability)

- Outdoor environment on site (preservation and creation of biotope, townscape and landscape, and outdoor amenities)

\section{Building Environmental Loadings}

- Energy (thermal load, use of natural energy, efficiency of systems, and efficient operations)

- Resources and materials (water conservation, recycled materials, sustainably harvested timber, materials with low health risks,

- Reuse and reusability, and avoidance of CFCs and halons)

- Off-site environment (air pollution, noise and vibration, odor, sunlight obstruction, light pollution, heat island effect, and local on local infrastructure)

Below is an example of CASBEE reporting documentation. References consulted for this review of CASBEE included: PC IBEC, 2006; CASBEE, 2004; CASBEE, 2006; JSBC, 2005; Murakami, 2003; CASBEE brochure; and HK Buildings Department, 2005. 

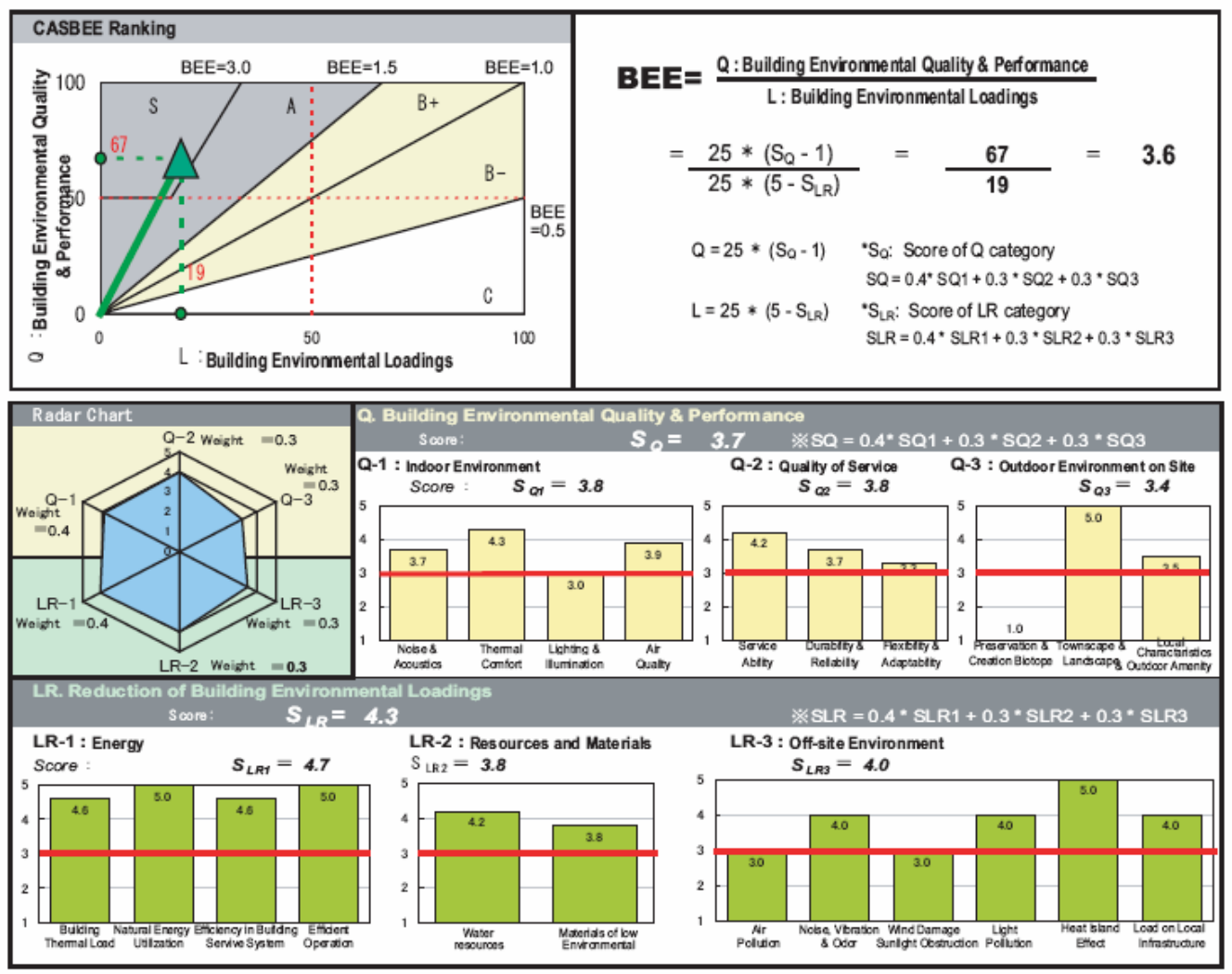

\section{GBTool}

GBTool was developed by the International Framework Committee for the Green Building Challenge, an international project that has involved more than 25 countries since 1998. GBTool is designed to be adapted by sponsors to reflect regional conditions and context. It includes criteria in categories such as Site Selection, Project Planning and Development; Environmental Loadings; Energy and Resource Consumption; Indoor Environmental Quality; Functionality; Long-Term Performance; and Social and Economic Aspects. Criteria are assessed using scales that are based on local benchmarks of "typical" practice; buildings can score -1 if below typical practice or from +1 to +5 , representing good to very high performance. All criteria must be scored, thus providing a complete assessment of the building. Both benchmarks of typical practice and weightings of criteria are established by the sponsoring organization to represent national, regional, or local codes, practice, context, conditions, and priorities. GBTool has evolved over time as it has been tested by participating countries and results have been presented at a series of international conferences. Originally addressing only an as-designed assessment, GBTool is developing versions to address pre-design, design, as built, and operations. The tool itself comprises two spreadsheets, one for data entry (to be completed by the project team) and one for establishing weights and benchmarks and completing the assessment (to be completed by third party sponsors or assessors). 
GBTool major categories of criteria include the following:

- Energy consumption is assessed through total use of non-renewable energy (embodied and operational), electrical peak demand for operations, use of renewable energy, and commissioning.

- Resource consumption is assessed through materials use (salvaged, recycled, bio-based and sustainably harvested, locally produced, designed for disassembly, re-use, or recycling) and water use for irrigation, building systems, and occupant use.

- Environmental loadings include greenhouse gas emissions, other atmospheric emissions, solid wastes, stormwater, wastewater, site impacts, and other local and regional impacts.

- Indoor environmental quality is assessed through indoor air quality, ventilation, temperature and relative humidity, daylight and illumination, and noise and acoustics.

- Other criteria include selection of appropriate site (in terms of land use, brownfields, access to transportation and amenities), project planning, urban design (density, mixed uses, compatibility, native plantings, and wildlife corridors), building controls, flexibility and adaptability, maintenance of operating performance, and a few social and economic measures.

Below is an example of GBTool documentation. References consulted for this review of GBTool included: PC GBTool, 2006; GBTool 1998, 2000, 2002, 2005; Todd, et al, 2001; GBC 1998; and SB, 2000, 2002, 2005.

\begin{tabular}{|c|c|c|c|c|c|c|c|c|c|}
\hline \multirow{2}{*}{\multicolumn{6}{|c|}{$\begin{array}{l}\text { Results for SHIIODOME } \\
\text { formance results based on } \\
\text { ailable during Operations Phase }\end{array}$}} & \multicolumn{4}{|c|}{ TOWER, Tokyo, Japan } \\
\hline & & & & & & $\begin{array}{r}\text { Active Phase } \\
\text { (set in Module A) }\end{array}$ & Ope & arations Pha & ase \\
\hline \multicolumn{6}{|c|}{ Relative Performance Results } & \multicolumn{4}{|c|}{ Key Facts About This Project } \\
\hline \multirow{2}{*}{\multicolumn{6}{|c|}{$0=$ Aoceptable Practice; $3=$ Good Practice; $5=$ Best Practice }} & \multicolumn{4}{|c|}{ 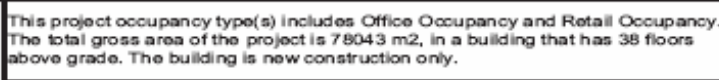 } \\
\hline & & & & & & \multirow[t]{2}{*}{$\begin{array}{l}\text { Asoumod lito span is } 100 \text { yoars. } \\
\text { Monotary units aro in Yon } \\
\end{array}$} & \multicolumn{3}{|c|}{$\begin{array}{l}\text { Amortization rato for ombodiod onergy of } \\
\text { oxisting mattorials is sot at o porcont. }\end{array}$} \\
\hline \multirow{2}{*}{4} & & & & & & & \multicolumn{3}{|c|}{$\begin{array}{l}\text { Thore is no oxisting bullding on the site that } \\
\text { can bo ro-usod. }\end{array}$} \\
\hline & & & & & & 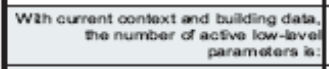 & 42 & $\begin{aligned} \text { Max. potertial } \\
\text { now-lewa: } \\
\text { paramekers }\end{aligned}$ & 50 \\
\hline \multirow[t]{2}{*}{3} & & & & & & 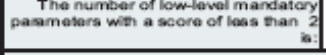 & 8 & 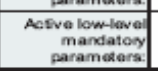 & 12 \\
\hline & & & & & & \multicolumn{2}{|c|}{ 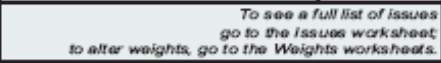 } & Activo Woights & $\begin{array}{l}\text { Wolghtod } \\
\text { scoros }\end{array}$ \\
\hline \multirow{3}{*}{2} & & & & & & \multicolumn{2}{|c|}{\begin{tabular}{|l|l|} 
A & $\begin{array}{l}\text { Site Selection, Project Planning and } \\
\text { Development }\end{array}$ \\
\end{tabular}} & $0 \%$ & 0.0 \\
\hline & & & & & & \multicolumn{2}{|c|}{ B Energy and Resource Consumption } & $24 \%$ & 2.5 \\
\hline & & & & & & \multicolumn{2}{|l|}{ C Environmental Loadings } & $19 \%$ & 3.2 \\
\hline \multirow[t]{3}{*}{0} & \multirow{3}{*}{ A } & \multirow{3}{*}{ B } & \multirow{3}{*}{$\mathrm{E}$} & \multirow{3}{*}{$\mathbf{F}$} & \multirow{3}{*}{ G } & \multicolumn{2}{|l|}{ D Indoor Environmental Quality } & $19 \%$ & 2.2 \\
\hline & & & & & & \multicolumn{2}{|c|}{$\begin{array}{l}\text { E Functionality and Controllability of } \\
\text { Building Systems }\end{array}$} & $14 \%$ & 3.6 \\
\hline & & & & & & \multicolumn{2}{|l|}{ F Long-Term Performance } & $14 \%$ & 2.1 \\
\hline \multirow{2}{*}{\multicolumn{6}{|c|}{ 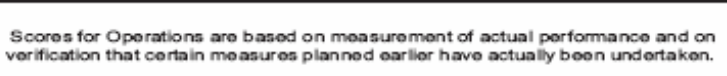 }} & \multicolumn{2}{|l|}{$G$ Social and Economic aspects } & $10 \%$ & 3.0 \\
\hline & & & & & & \multicolumn{3}{|c|}{ Total welghted building score } & 2.7 \\
\hline
\end{tabular}




\section{Green Globes ${ }^{\mathrm{TM}}$ US}

Green Globes ${ }^{\mathrm{TM}}$ US was adapted from the Green Globes Canada rating system in 2004. Green Globes Canada was developed as a web-based version of the combination of BREEAM Canada and Green Leaf. The development of Green Globes ${ }^{\text {TM }}$ US is funded by The Green Building Initiative. The Green Globes ${ }^{\mathrm{TM}}$ US system is an on-line tool designed for use by architects and builders for any size commercial building. The preliminary assessment occurs after conceptual design and the final assessment occurs after the construction documentation stage. Green Globes allows its users to evaluate their systems based on the amount of applicable available points, having the option of "not applicable" in some categories. Projects that are third-party verified and have achieved over $35 \%$ of the points can earn a rating of 1 to 4 Green Globes. Unless otherwise noted, this review used the text form of Green Globes ${ }^{\mathrm{TM}}$ US Version 1.0 (April 2006 release). Version 0 was the text form version available when this review began, and as of May 2006, Version 0 is the only version available for on-line interactive use. During the rating system review, there was a period of time (approximately 6 weeks) when no text form of a rating system was available on-line.

Green Globes major categories of criteria include the following:

- Project Management (integrated design, environmental purchasing, commissioning, emergency response plan)

- Site (site development area, reduce ecological impacts, enhancement of watershed features, site ecology improvement)

- Energy (energy consumption, energy demand minimization, "right sized" energy-efficient systems, renewable sources of energy, energy-efficient transportation)

- Water (flow and flush fixtures, water-conserving features, reduce off-site treatment of water)

- Indoor Environment (effective ventilation systems, source control of indoor pollutants, lighting design and integration of lighting systems, thermal comfort, acoustic comfort)

- Resource, Building Materials and Solid Waste (materials with low environmental impact, minimized consumption and depletion of material resources, re-use of existing structures; building durability, adaptability and disassembly; and reduction, re-use and recycling of waste)

Below is an example of Green Globes Version 0 documentation found on-line of a Canadian building. References consulted for this review of Green Globes included: PC GBI, 2006; ECD, 2002; ED+C, 2005; GBI, 2006a-c; Green Globes a-b; and Issaquah Highlands, 2006. 


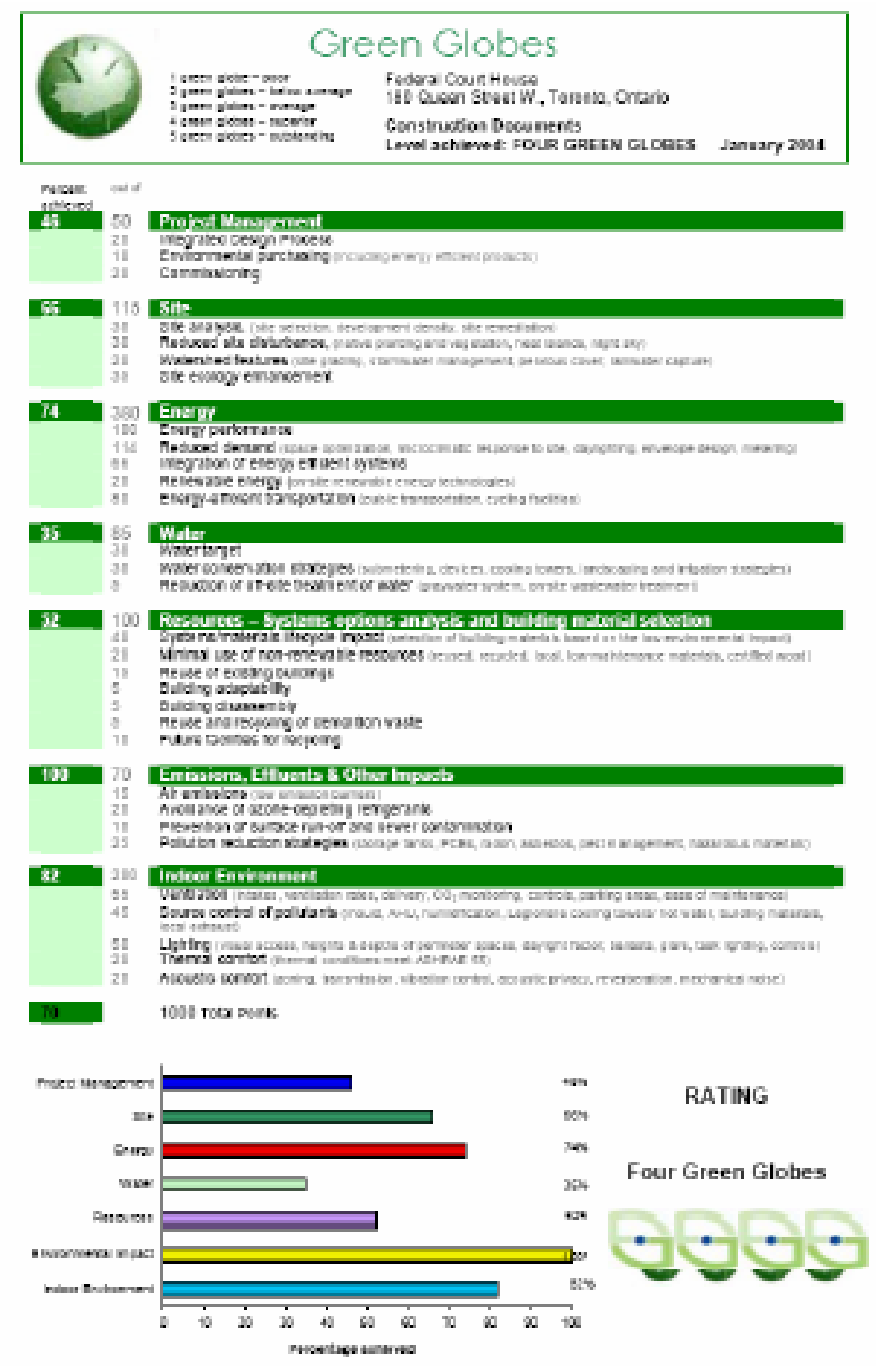

\section{LEED $^{\circledR}$}

LEED $^{\circledR}$ (Leadership in Energy and Environmental Design) was developed and piloted in the U.S. in 1998 as a consensus-based building rating system based on the use of existing building technology. The development of LEED $^{\circledR}$ has been through the U.S. Green Building Council member committees. The rating system addresses specific environmental building related impacts using a whole building environmental performance approach. In addition to LEED-NC (for new construction and major renovations), there are versions for existing buildings, commercial interiors, core and shell, homes, and neighborhood development. There are also application guides that can be used to increase the applicability and flexibility of LEED ${ }^{\circledR}$ (e.g., multiple buildings and campuses, schools, health care, laboratories, lodging, and retail (pilot)). Unless otherwise noted, this review used LEED-NC Version 2.2. The LEED Reference Guide presents detailed information on how to achieve the credits within the following major categories:

- Sustainable Sites (construction related pollution prevention, site development impacts, transportation alternatives, stormwater management, heat island effect, and light pollution) 
- Water Efficiency (landscaping water use reduction, indoor water use reduction, and wastewater strategies)

- Energy and Atmosphere (commissioning, whole building energy performance optimization, refrigerant management, renewable energy use, and measurement and verification)

- Materials and Resources (recycling collection locations, building reuse, construction waste management, and the purchase of regionally manufactured materials, materials with recycled content, rapidly renewable materials, salvaged materials, and sustainably forested wood products)

- Indoor Environmental Quality (environmental tobacco smoke control, outdoor air delivery monitoring, increased ventilation, construction indoor air quality, use low emitting materials, source control, and controllability of thermal and lighting systems)

- Innovation and Design Process (LEED ${ }^{\circledR}$ accredited professional, and innovative strategies for sustainable design)

Below is an example of LEED ${ }^{\circledR}$ Version 2.0 documentation found on-line. References consulted for this review of LEED ${ }^{\circledR}$ included: PC USGBC, 2006; USGBC, 2004;

USGBC, 2005; Lewis, Miranda, 2002; Scheuer, Keoleian, 2002; and USGBC, 2006. 


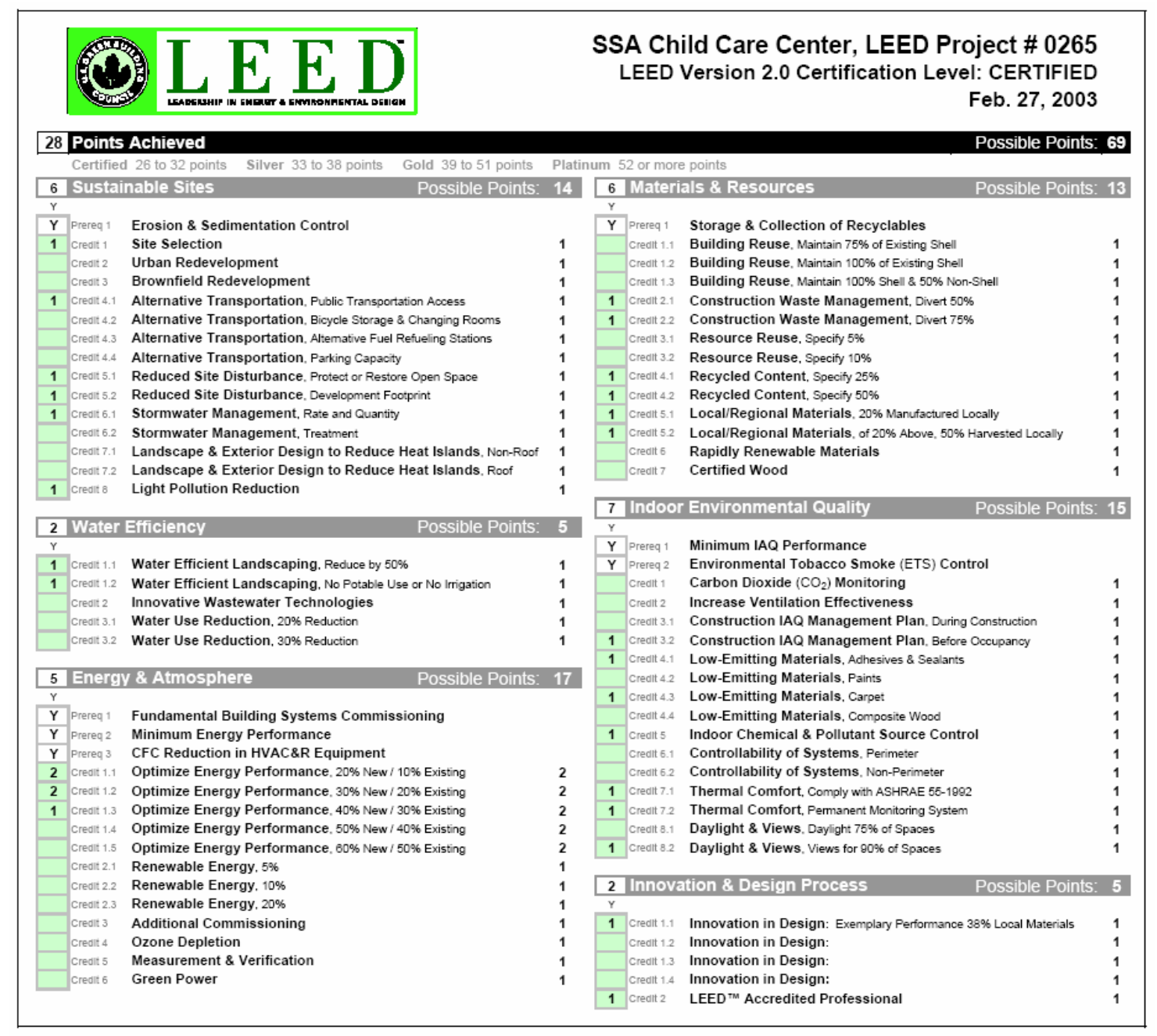

\section{Review of Applicable Rating Systems}

The five sustainable building rating systems being reviewed in this document are listed in Table 3. Throughout the remainder of the document these systems will be referred to by its acronym or the shortest version of its title. As stated earlier, unless otherwise noted, the rating system information used for this review was identified and publicly available during January 15, 2006 through May 1, 2006. A brief description of each rating system was provided in Section VI. This section documents how each rating system meets the seven review criteria shown in Table 4.

The information for each rating system was initially gathered through publicly available and relatively easy to locate information using the internet, conference proceedings and journal articles. A review of the rating systems information was offered to both the rating system owners and known technical experts in sustainable building rating systems in order to identify additional information and to clarify information where needed. Rating system owner feedback was received from all of the rating system owners except for BREEAM although there were multiple requests and extended deadlines. 
The following tables are organized by the review criteria. Quantifiable and comparable information was collected for each rating system. Where feasible, this information has been captured in data tables to allow for comparison and additional, relevant information is provided following the tables as appropriate. The key for the tables is the following:

\begin{tabular}{|c|l|}
\hline \multicolumn{2}{|c|}{ Key } \\
\hline$\checkmark$ & Does Meet Criterion \\
\hline$O$ & Under development \\
\hline$\checkmark /-$ & Meets Criterion with Exception(s) \\
\hline- & Does Not Meet Criterion \\
\hline (blank) & Information Unknown \\
\hline n/a & Not applicable \\
\hline
\end{tabular}

When the answer can be a simple "Does Meet Criterion" or "Does Not Meet Criterion" it is unlikely additional information will be provided below the tables. When the current information available results in an "Under development" or "Meets Criterion with Exceptions" response, there will be additional information provided below the tables.

Table 5 summarizes the data gathered for the Applicability review criterion.

Applicability

Type of Projects: Rating system can be used on all GSA project types, such as New Construction,

Major Renovations, Tenant Build-Out (leases), and Operations \& Maintenance.

Type of Buildings: Rating system can be used on all GSA building types, such as Offices Buildings,

Courthouses, and Border Stations.

Table 5. Applicability

\begin{tabular}{|c|c|c|c|c|c|c|c|}
\hline & \multicolumn{7}{|c|}{ Applicability } \\
\hline & \multicolumn{4}{|c|}{ Type of Projects } & \multicolumn{3}{|c|}{ Types of Buildings } \\
\hline & $\begin{array}{l}\mathrm{New} \\
\text { Construction }\end{array}$ & $\begin{array}{l}\text { Major } \\
\text { Renovations }\end{array}$ & $\begin{array}{l}\text { Tenant } \\
\text { Build- } \\
\text { Out }\end{array}$ & $\begin{array}{l}\text { Operations } \\
\& \\
\text { Maintenance }\end{array}$ & $\begin{array}{l}\text { Office } \\
\text { Buildings }\end{array}$ & Courthouses & $\begin{array}{l}\text { Border } \\
\text { Stations }\end{array}$ \\
\hline BREEAM & $\checkmark$ & $\checkmark$ & - & $\checkmark$ & $\checkmark$ & $\checkmark$ & $\checkmark$ \\
\hline CASBEE & $\checkmark$ & $\checkmark$ & - & $\checkmark$ & $\checkmark$ & $\checkmark$ & $\checkmark$ \\
\hline GBTool & $\checkmark$ & $\checkmark$ & - & $\mathrm{O}$ & $\checkmark$ & $\checkmark$ & $\checkmark$ \\
\hline Green Globes US & $\checkmark$ & $\mathrm{O}$ & 0 & $\mathrm{O}$ & $\checkmark$ & $\checkmark$ & $\checkmark$ \\
\hline LEED & $\checkmark$ & $\checkmark$ & $\checkmark$ & $\checkmark$ & $\checkmark$ & $\checkmark$ & $\checkmark$ \\
\hline
\end{tabular}

A Green Globes ${ }^{\mathrm{TM}}$ US module for existing buildings is in the pilot development stage, as an adaptation of the Green Globes Canada modules. According to The Green Building Initiative feedback, the Green Globes ${ }^{\mathrm{TM}}$ US existing buildings module is used for the major renovation, tenant build-out and operations and maintenance types of projects. 
Although none of these sustainable building rating systems have specific modules for courthouses or border stations, all of the rating system documentation implied that the office version could be or has been used for these building types.

Table 6 summarizes the data gathered for the Development review criterion. A " $\checkmark$ " in the System Management column indicates if there was any development, funding, or management of the rating system by a particular entity. For example if a rating system had some private industry involvement but no direct private industry funding it would still receive a " $\checkmark$ ".

\section{Development}

System Management: Identify the level of involvement in the development, funding, and management of the rating system by Government, Private Industry, Non-Governmental Organizations, and others.

Development Approach: Identify if system was developed using a consensus-based approach, life cycle analysis, expert opinion approach, or other.

Openness of Operations: Ability to gather information on the rating system membership and represented organizations.

Transparency of Rating System: Ability to access relevant information either from the internet or other sources.

Table 6. Development

\begin{tabular}{|l|c|c|c|c|c|c|}
\hline \multirow{2}{*}{} & \multicolumn{5}{|c|}{ Development } \\
\cline { 2 - 7 } & \multicolumn{3}{|c|}{ System Management } & \multicolumn{2}{c|}{ Development Approach } \\
\cline { 2 - 7 } & Government & $\begin{array}{c}\text { Private } \\
\text { Industry }\end{array}$ & NGO & $\begin{array}{c}\text { Life } \\
\text { Consensus- } \\
\text { based }\end{array}$ & $\begin{array}{c}\text { Cycle } \\
\text { Analysis }\end{array}$ & $\begin{array}{c}\text { Expert } \\
\text { Opinion }\end{array}$ \\
\hline BREEAM & & $\checkmark$ & $\checkmark$ & & & \\
\hline CASBEE & $\checkmark /-$ & $\checkmark$ & $\checkmark$ & $\checkmark$ & $\checkmark /-$ & $\checkmark$ \\
\hline GBTool & $\checkmark$ & - & $\checkmark$ & $\checkmark$ & $\checkmark$ & $\checkmark$ \\
\hline Green Globes US & $\checkmark /-$ & $\checkmark$ & $\checkmark$ & $\bigcirc$ & $\checkmark /-$ & $\checkmark$ \\
\hline LEED & $\checkmark$ & $\checkmark$ & $\checkmark$ & $\checkmark$ & $\bigcirc$ & $\checkmark$ \\
\hline
\end{tabular}

BREEAM was co-developed by the Building Research Establishment Ltd. (BRE) and ECD (now part of Faber Maunsell's Sustainable Development Group). CASBEE is managed by the newly-formed Japan Sustainable Building Consortium which is a nongovernmental organization comprised of industry, the Japanese government, and academic members GBTool has been developed and revised by the International Framework Committee (IFC) composed of representatives of all participating countries (approximately 25 countries have been involved thus far), including the U.S. government. Green Globes ${ }^{\mathrm{TM}}$ US was developed from Green Globes Canada, funded by the Green Building Initiative. The Green Building Initiative is a Section 501(c)3 non-profit organization. Green Globes Canada is maintained by the Canadian Energy Efficiency Alliance. The Green Globes Canada copyright and trademark are owned by ECD Energy and Environment Canada. The adaptation of the Canadian tool to Green Globes $^{\mathrm{TM}}$ US was initially completed by one individual. Government involvement has been Canadian, not U.S. LEED ${ }^{\circledR}$ has received U.S. government funding and was 
developed by the U.S. Green Building Council member committees. The U.S. Green Building Council is a 501(c)3 non-profit organization.

The rating systems self-identified their development approach which resulted in each of them stating they used expert opinions and various levels of "consensus-based" development. The Green Building Initiative plans to follow ANSI approved procedures to make Green Globes ${ }^{\mathrm{TM}}$ US a consensus-based standard. An ANSI technical committee has been formed.

CASBEE has a mechanism for including life cycle analysis in the process as an optional assessment, but the life cycle analysis does not impact the primary Building Environmental Efficiency assessment. For GBTool, life cycle analysis (LCA) was used as the basis for materials criteria and embodied energy criteria in earlier versions; in the 2005 version, materials credits were based on attributes because many users did not have access to LCA data. According to the Green Building Initiative, Green Globes ${ }^{\text {TM }}$ U.S. awards points in the Resources section for carrying out a life cycle assessment. Green Globes recommends using Athena at the Schematic Design Stage and BEES at the Construction Documentation Stage. The life cycle impact of design choices was considered in the development of LEED $^{\circledR}$, however, the inclusion of LCA into the $\mathrm{LEED}^{\circledR}$ rating systems is under development for Version 3.0.

Tables 7.1 and 7.2 summarize the data gathered for the Usability review criterion.

\section{Usability}

Cost: Identify the cost of using a system, including cost for use or rating system materials, cost of project registration, fees associated with certification, and time typically needed to complete an application.

Ease of Use: Complexity of the tools and technical knowledge needed to complete rating system process, especially for the optimization of energy use, environmentally preferable products use, and indoor environmental quality enhancement.

Product support: Availability and responsiveness of direct requests for assistance, availability of training, and usability of information available on the website, through case studies, documented inquiries, and frequently asked questions.

Table 7.1. Usability (1)

\begin{tabular}{|l|c|c|c|c|c|c|c|c|}
\hline \multirow{2}{*}{} & \multicolumn{9}{|c|}{ Cost } & \multicolumn{9}{c|}{ Product Support } \\
\cline { 2 - 10 } & $\begin{array}{c}\text { Project } \\
\text { Registration }\end{array}$ & Certification Fees & $\begin{array}{c}\text { Time } \\
\text { Est. }\end{array}$ & $\begin{array}{c}\text { Case } \\
\text { Studies }\end{array}$ & $\begin{array}{c}\text { Record of } \\
\text { Inquiries }\end{array}$ & FAQ & $\begin{array}{c}\text { Training } \\
\text { available }\end{array}$ & $\begin{array}{c}\text { Available } \\
\text { in } \\
\text { English }\end{array}$ \\
\hline BREEAM & & $\$ 1,290$ each stage & & - & - & - & $\checkmark$ & $\checkmark$ \\
\hline CASBEE & $\$ 0$ & $\$ 3,570-\$ 4,500$ & $3-7$ days & $\checkmark$ & $\checkmark /-$ & $\checkmark /-$ & $\checkmark$ & $\checkmark /-$ \\
\hline GBTool & $\mathrm{n} / \mathrm{a}$ & $\mathrm{n} / \mathrm{a}$ & & $\checkmark$ & - & - & - & $\checkmark$ \\
\hline Green Globes US & $\$ 500$ & Avg $\$ 4000$ & $5-7$ days & $\checkmark$ & - & $\checkmark$ & $\checkmark /-$ & $\checkmark$ \\
\hline LEED & $\$ 450$ & $\$ 1,250-\$ 17,500$ & 7 weeks & $\checkmark$ & $\checkmark$ & $\checkmark$ & $\checkmark$ & $\checkmark$ \\
\hline
\end{tabular}

If using BREEAM, a maximum of $\$ 17,500$ is the expected cost of the needed design and procurement assessments. GBTool requires "upfront" work to establish the 
weighting factors, but once that is completed, the level of effort per building decreases. U.S. Green Building Council membership dues range from $\$ 300$ to $\$ 12,500 /$ year based on type of organization. The LEED ${ }^{\circledR}$ cost of applying the system is based on U.S. Green Building Council member prices and for LEED ${ }^{\circledR}$ Version 2.2, which are based on the size of the building. Certification fees for LEED ${ }^{\circledR}$ Versions 2.0 and 2.1 range from $\$ 1,200$ to $\$ 6,000$.

These rating systems require varying levels of specialized sustainable design knowledge to be effectively used. The time and cost associated with this specialized knowledge is an important consideration but it is not addressed as part of this analysis. For all of the systems, the time estimated to complete the rating system documentation depends on the knowledge level of the people involved and the complexity of the building. The costs and challenges of using a system are expected to be higher initially and decrease over time once the system is known by the design professionals (assuming no major rating system changes have occurred). GSA standards are high and documentation that buildings meet those standards is required. Therefore, the cost to prepare detailed documentation, specific to the rating system is considered a standard operating cost and is not a criterion for this review.

CASBEE has a record of inquiries and frequently asked questions (FAQs), but it is not currently available in English. Training is available in major Japanese cities. Some of the CASBEE information, such as case studies, is available in both English and Japanese, but other aspects of the system are not currently available in English. GBTool is typically applied by those that have been involved in the development; therefore there is no training available for its use. Green Globes ${ }^{\mathrm{TM}} \mathrm{US}$ has a webpage dedicated to training, but the page was posted as "under development" during this rating system review (as of 5/1/06). In-person training has been performed and can be scheduled. LEED ${ }^{\circledR}$ Workshops, LEED ${ }^{\circledR}$ Topic Modules, web-based professional accreditation, project certification, and integrated design, and the Greenbuild conference are opportunities for LEED $^{\circledR}$ related training. Greater than 30,000 people have been trained and the U.S. Green Building Council has 23,000 LEED ${ }^{\circledR}$ Accredited Professionals as part of their technical network. 
Table 7.2. Usability (2)

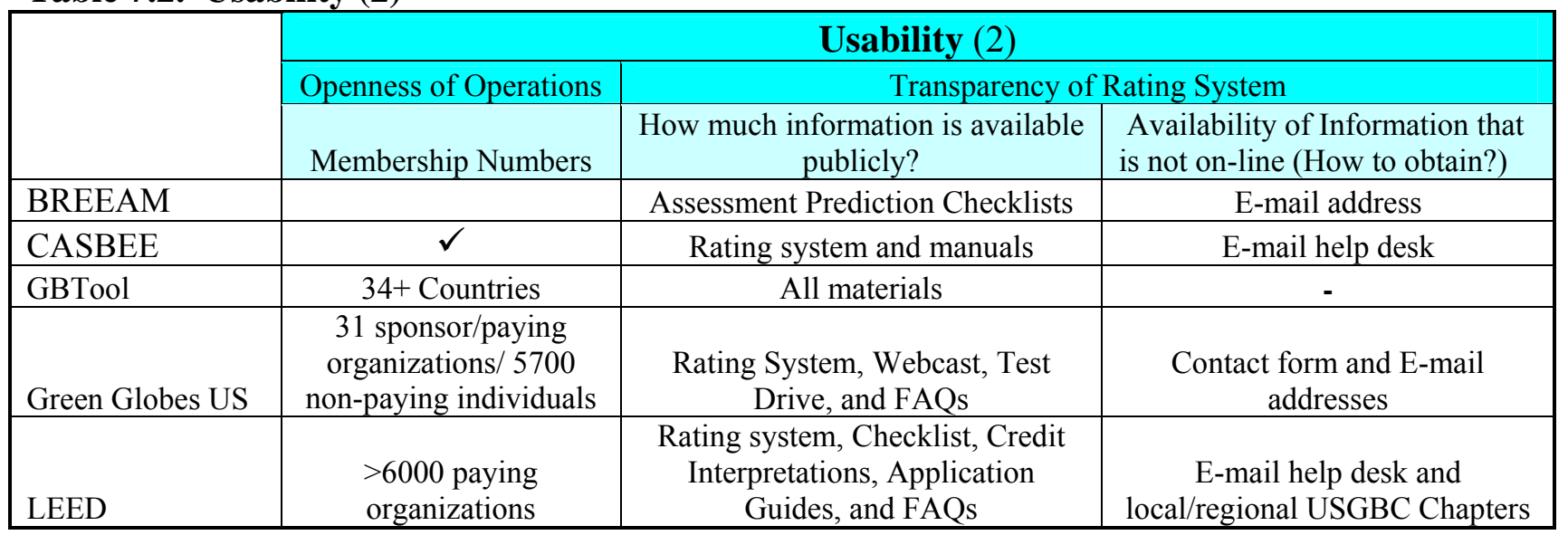

There are various types of membership in the organizations sponsoring the systems some have organizations as the member unit while others have individuals; some have free memberships, others have fees for memberships, and others have a combination of the two. BREEAM enrollment information was not found on-line, and as mentioned earlier, there was no response to requests for additional information. The CASBEE members list is available on-line. The Green Building Initiative has both organizational memberships for a fee and individual memberships that are free.

Table 8 summarizes the data gathered for the System Maturity review criterion.

\section{System Maturity}

System Age: Identify when the rating system was developed, first used, first available for public use, and when the most recent revision was completed.

Number of Buildings: Identify the number of buildings participating in the rating system and the number of buildings that have completed the process for denotation as a green building.

Stability of system: Identify the processes that allow for full implementation of a rating system, including development, testing, and review process, systems for upgrades, process for modifications, and expected frequency of modifications.

Table 8. System Maturity

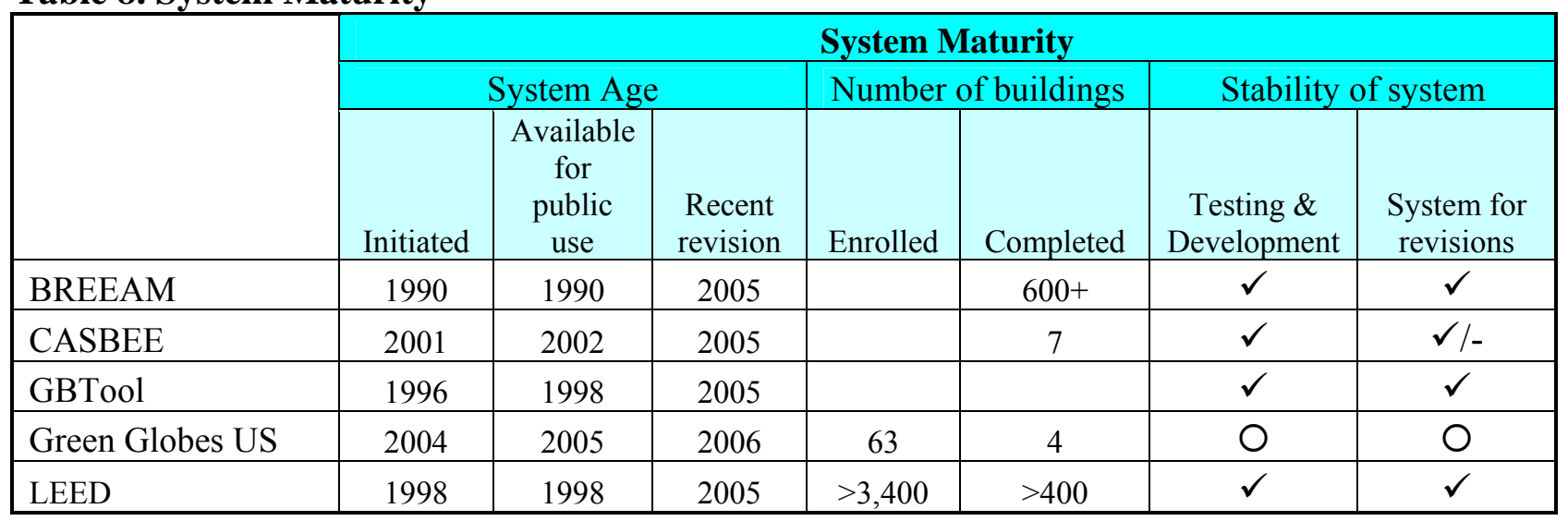

BREEAM is updated every fall. CASBEE has a major modification once a year.

GBTool has been updated 4 times since it was established following the testing of the 
tool and presentations at international conferences. All of the Green Globes ${ }^{\mathrm{TM}}$ US buildings that have been completed are pilot studies using Version 0. The U.S. Green Building Council has the LEED Product Development and Maintenance Manual available on-line that governs how changes are made to the LEED $^{\circledR}$ rating systems. New rating systems have detailed steps they must follow including pilot testing and a public comment period. The existing systems can have minor updates as frequently as one time a year and major updates are expected every 3-5 years.

Table 9 summarizes the data gathered for the Technical Content review criterion. The rating systems were compared using the WBDG sustainable design and development principles. Additional comparable information on the technical content of these five rating systems is summarized in Appendix C.

\section{Technical Content}

Relevance to Sustainability: Representative of sustainable design needs of the Federal government as identified in the Whole Building Design Guide.

Thoroughness: Detailed review of how rating system addresses key sustainable design characteristics such as optimizing Energy Use, using Environmentally Preferable Products, and enhancing Indoor Environmental Quality (IEQ).

Measurement comparison: Identify the mechanism used as the baseline for comparison, such as industry benchmark or checklist.

\section{Table 9. Technical Content}

\begin{tabular}{|c|c|c|c|c|c|c|c|}
\hline & \multicolumn{7}{|c|}{ Technical Content } \\
\hline & $\begin{array}{c}\text { Optimize } \\
\text { Site } \\
\text { Potential } \\
\end{array}$ & $\begin{array}{c}\text { Optimize } \\
\text { Energy } \\
\text { Use }\end{array}$ & $\begin{array}{l}\text { Protect } \\
\text { and } \\
\text { Conserve } \\
\text { Water }\end{array}$ & $\begin{array}{c}\text { Use } \\
\text { Environmentally } \\
\text { Preferable } \\
\text { Products } \\
\end{array}$ & $\begin{array}{c}\text { Enhance } \\
\text { IEQ }\end{array}$ & $\begin{array}{c}\text { Optimize } \\
\text { Operational } \\
\& \\
\text { Maintenance } \\
\text { Practices } \\
\end{array}$ & Other \\
\hline BREEAM & $15 \%$ & $25 \%$ & $5 \%$ & $10 \%$ & $15 \%$ & $15 \%$ & $15 \%$ \\
\hline CASBEE & $15 \%$ & $20 \%$ & $2 \%$ & $13 \%$ & $20 \%$ & $15 \%$ & $15 \%$ \\
\hline GBTool & $\begin{array}{c}15 \% \\
12.5 \%\end{array}$ & $\begin{array}{c}25 \% \\
20.8 \%\end{array}$ & & & $\begin{array}{c}15 \% \\
16.7 \%\end{array}$ & $\begin{array}{c}15 \% \\
16.6 \%\end{array}$ & $\begin{array}{c}30 \% \\
33.4 \%\end{array}$ \\
\hline Green Globes US & $11.5 \%$ & $36 \%$ & $10 \%$ & $10 \%$ & $20 \%$ & & $12.5 \%$ \\
\hline LEED & $20 \%$ & $25 \%$ & $7 \%$ & $19 \%$ & $22 \%$ & & $7 \%$ \\
\hline
\end{tabular}

BREEAM has $15 \%$ of its points that don't fit within the WBDG categories. That $15 \%$ is in the Management category that includes best practices for construction and construction waste management. CASBEE has $15 \%$ of its points in "other", which included pollution mitigation and solar energy gain for the Offsite Environment category. GBTool weightings for categories are established by the user based off of GBTool's default weightings (shown on the bottom part of the row). The top part of the row is an example set of weights established for the GSA Denver Courthouse's participation in Green Building Challenge 2005. Green Globes ${ }^{\mathrm{TM}}$ US has $12.5 \%$ of its points in "other", which included Project Management (integrated design process, commissioning, and emergency planning) and Emissions (boiler air emissions, ozone depletion and global warming, contamination of sewers and waterways, land and water pollution, integrated pest management, and storage of hazardous material). LEED ${ }^{\circledR}$ allows for $7 \%$ of its credits to be "innovation" credits. These credits could be targeted 
at unique design strategies, unique pieces of equipment, the expected operational and maintenance practices of the building, or hiring a LEED ${ }^{\circledR}$ Accredited Professional.

U.S. building codes and standards are referenced in both Green Globes ${ }^{\mathrm{TM}}$ US and LEED $^{\circledR}$. LEED ${ }^{\circledR}$ establishes minimum code performance for various technical elements as part of the "pre-requisites" of the system. If a building design does not meet those minimum standards it cannot receive LEED $^{\circledR}$ certification. Note that identifying how successful the rating systems are at driving the building design beyond code was not part of the review.

Tables 10.1 and 10.2 summarize the data gathered for the Measurability \& Verification review criteria.

\section{Measurability \& Verification}

Standardization: Established collection procedures exist.

Quantification: Numeric measurements facilitate absolute and relative performance evaluation.

Certification/Verification Process: Define system for verifying sustainable design practices for a particular application, including who evaluates the application and at what level of detail do they review the applications.

Documentation: Identify what type of documentation is necessary and at what stages of the project the information is collected.

Verifiable/Defendable: Provide documentation of the actual state of the building with respect to the rating system evaluation; include costs and benefits of using the rating system.

\section{Table 10.1. Measurability}

\begin{tabular}{|l|c|c|c|c|}
\hline \multirow{2}{*}{} & \multicolumn{4}{|c|}{ Measurability } \\
\cline { 2 - 5 } & Measurement comparison & Standardization & Quantification \\
\cline { 2 - 5 } & Benchmark & Checklist & $\begin{array}{c}\text { Established } \\
\text { collection } \\
\text { procedures }\end{array}$ & $\begin{array}{c}\text { Numeric } \\
\text { Measurements }\end{array}$ \\
\hline BREEAM & - & $\checkmark$ & & $\checkmark$ \\
\hline CASBEE & $\checkmark$ & & $\checkmark$ & $\checkmark$ \\
\hline GBTool & $\checkmark$ & - & $\checkmark$ & $\checkmark /$ - \\
\hline Green Globes US & $\checkmark$ & $\checkmark$ & $\checkmark /$ - & $\checkmark$ \\
\hline LEED & $\checkmark$ & $\checkmark$ & $\checkmark$ & $\checkmark$ \\
\hline
\end{tabular}

GBTool criteria include both qualitative and quantitative measurements. Green Globes $^{\mathrm{TM}}$ US uses the webtool to complete a checklist for a building project. Information was not found on the Green Globes ${ }^{\mathrm{TM}}$ US or Green Globes Canada websites as to how much additional documentation would need to be collected to support the completed checklist. 
Table 10.2. Verification

\begin{tabular}{|c|c|c|c|c|c|}
\hline & \multicolumn{5}{|c|}{ Verification } \\
\hline & \multicolumn{2}{|r|}{ Documentation } & \multicolumn{3}{|c|}{ Certification/Verification Process } \\
\hline & Type & At what stages of project & Level of detail of check & Third Party & Assessor Qualification \\
\hline BREEAM & & & $\begin{array}{l}\text { Detailed Assessment of } \\
\text { documentary evidence }\end{array}$ & $\checkmark$ & Trained and licensed by BRE \\
\hline CASBEE & $\begin{array}{l}\text { On-line Excel } \\
\text { spreadsheet }\end{array}$ & $\begin{array}{l}\text { Preliminary design, execution design, } \\
\text { and completion. }\end{array}$ & $\begin{array}{l}\text { Depends on the } \\
\text { Assessment tools used. } \\
\text { Document review is } \\
\text { required. }\end{array}$ & $\checkmark$ & $\begin{array}{l}\text { Trained and must pass an } \\
\text { assessor examination. Must be a } \\
\text { first-class architect to qualify. }\end{array}$ \\
\hline GBTool & $\begin{array}{l}\text { On-line Excel } \\
\text { spreadsheet }\end{array}$ & After Design is complete & $\mathrm{n} / \mathrm{a}$ & - & $\mathrm{n} / \mathrm{a}$ \\
\hline Green Globes US & On-line tool & $\begin{array}{l}\text { Concept Design, Construction } \\
\text { Documentation \& Site Inspection }\end{array}$ & $\begin{array}{l}\text { Review of documentation } \\
\text { \& Site inspection. }\end{array}$ & $\checkmark$ & $\mathrm{O}$ \\
\hline LEED & $\begin{array}{l}\text { On-line and/or } \\
\text { hard copy }\end{array}$ & $\begin{array}{l}\text { Design Review \& Construction } \\
\text { Review }\end{array}$ & $\begin{array}{l}\text { Administrative and Credit } \\
\text { Audit }\end{array}$ & $\checkmark$ & $\begin{array}{l}\text { Trained and must pass an } \\
\text { assessor examination. }\end{array}$ \\
\hline
\end{tabular}

In BREEAM, each category has between 7 and 70 points in which the building could be awarded all or none of the points. In CASBEE, some of the indicators are measured according to benchmarks set by current laws, guidelines and expected practice. For GBTool, each country has a third party team that establishes benchmarks for each criterion. The criteria include a mix of quantitative and qualitative measures. Green Globes $^{\mathrm{TM}}$ US uses the EPA Target Finder as an energy benchmark and prescriptive paths for smaller office buildings. There was sample on-line questionnaire, but during this review, details on the information that would need to be collected and the collection procedures were not available. Following the completion of the American National Standards Institute (ANSI) process, the Green Building Initiative expects a third party will train and authorize verifiers.

Tables 11.1 and 11.2 summarize the data gathered for the Communicability review criterion.

\section{Communicability}

Clarity: Well-defined, easily communicated, and clearly understood among multiple parties.

Versatility: Number of systems that use it as its basis for development or comparison.

Comparability: Amenable to normalization for comparisons over varying building types, locations, years, or different sustainable design characteristics.

Results Usability: Usability of rating system documentation for communicating the accomplishments of the building project.

\section{Table 11.1. Communicability (1)}

\begin{tabular}{|c|c|c|c|c|}
\hline & \multicolumn{4}{|c|}{ Communicability (1) } \\
\hline & \multicolumn{3}{|c|}{ Clarity } & \multirow{2}{*}{$\begin{array}{c}\text { Versatility } \\
\text { Basis for } \\
\text { development }\end{array}$} \\
\hline & $\begin{array}{l}\text { Well- } \\
\text { defined }\end{array}$ & $\begin{array}{l}\text { Results easily } \\
\text { communicated }\end{array}$ & $\begin{array}{l}\text { Process \& Rating } \\
\text { System Information } \\
\text { clearly understood }\end{array}$ & \\
\hline BREEAM & $\checkmark$ & $\checkmark$ & - & 12 \\
\hline CASBEE & $\checkmark$ & $\checkmark$ & $\sqrt{ } /-$ & 1 \\
\hline GBTool & $\checkmark$ & - & - & 5 \\
\hline Green Globes US & $\checkmark /-$ & $\checkmark$ & 0 & 0 \\
\hline LEED & $\checkmark$ & $\checkmark$ & $\checkmark$ & 10 \\
\hline
\end{tabular}


Detailed BREEAM rating system information is available through the assessors, but a current version of the system was not publicly available for purchase. The CASBEE rating system manual offers specific definitions of criteria for all building types, which means it is more difficult to comprehend the system quickly. The availability variability of the Green Globes ${ }^{\mathrm{TM}}$ US on-line information (from January through 5/1/06) created a challenge for locating key, consistent rating system information and for verifying the rating system feedback that was provided during the review cycle.

With respect to the versatility criterion, BREEAM, LEED ${ }^{\circledR}$, and GBTool have been used as the development basis of new rating systems. Green Globes ${ }^{\mathrm{TM}}$ US is adapted from Green Globes Canada, which has been used as a development basis for at least two other tools.

Table 11.2. Communicability (2)

\begin{tabular}{|l|l|l|}
\hline \multirow{2}{*}{} & \multicolumn{2}{|c|}{ Communicability (2) } \\
\cline { 2 - 3 } & \multicolumn{1}{|c|}{ Comparability } \\
\cline { 2 - 3 } & \multicolumn{1}{|c|}{ Results Representation } & \multicolumn{1}{c|}{ Result Product } \\
\hline BREEAM & Pass, Good, Very Good, Excellent & Certificate \\
\hline CASBEE & "spider web" diagram, histograms and BEE graph & $\begin{array}{l}\text { Certificate and website published } \\
\text { results }\end{array}$ \\
\hline GBTool & Range of detailed and broad Histograms & n/a \\
\hline Green Globes US & $\begin{array}{l}\text { One to four globes }(1=35-54 \%, 2=55-69 \%, 3=70- \\
84 \%, 4=+85 \%)\end{array}$ & Plaque, report and case study \\
\hline LEED & $\begin{array}{l}\text { Certified }(40 \%), \text { Silver }(50 \%), \text { Gold }(60 \%), \\
\text { Platinum }(80 \%)\end{array}$ & Award letter, certificate and plaque \\
\hline
\end{tabular}

Rating systems are only a means to the goal of a high quality, low environmental impact building. To meet the GSA reporting needs, the rating systems must be able to clearly communicate an overall performance rating without compromising detail. (Cole, 2001) The rating system needs to be sufficiently universal to facilitate comparison of performance across the various regions and building types. It is useful for GSA to use a common assessment and communication method for comparability across Federal agencies, GSA building types, and varying project types (new construction, existing buildings, etc.). The rating system results must have a minimal range of possible interpretations and offer a consistent, unambiguous summary of results. All of the rating systems have a clear way of representing the results of the rating system assessment. Examples can be found on their main webpages. LEED ${ }^{\circledR}$ uses the same representation for its different versions for new construction, existing buildings, commercial interiors, core and shell, homes, and neighborhood development, which makes it easy to compare the relative achievement of different project and building types. 


\section{Summary}

There are many rating system and sustainable design tools that offer potentially useful techniques for building design depending on the needs of the user. Five sustainable building rating systems were reviewed in detail based on Federal and GSA drivers:

- BREEAM (Building Research Establishment's Environmental Assessment Method)

- CASBEE (Comprehensive Assessment System for Building Environmental Efficiency)

- GBTool

- Green Globes ${ }^{\mathrm{TM}} \mathrm{US}$

- LEED $^{\circledR}$ (Leadership in Energy and Environmental Design)

The purpose of this document is to offer information to assist in the comparison of sustainable building rating systems. GSA has identified that the ratings systems need to address the following elements:

- A system that is applicable to the large scale and complexity of federal building projects.

- A stable rating system such that the evaluation of building performance is not subject to drastic change.

- A system which tracks quantifiable achievements in sustainable design and is third party verified by a qualified assessor.

- A system used in the current market with practitioner awareness.

A description of how each of the potentially relevant sustainable building rating systems addressed these elements is summarized below.

- BREEAM has a long track record in the United Kingdom, but it is not extensively used in the U.S. and it is difficult to obtain current information about the system. Based on the information available, it would not be applicable to all of the GSA project types, specifically tenant build-out for leases. BREEAM is updated annually; however, the current version is not publicly available for purchase and must be acquired through a licensed assessor. The licensed assessor organization determines the BREEAM rating based on quantifiable sustainable design achievements. Although most in the sustainable design profession are aware of BREEAM and many rating systems have used it as their development basis, the rating system results are neither used nor recognized by U.S. design professionals.

- CASBEE is a relatively new system developed for the Japanese market that is available in English, but has not been tested in the U.S. However, CASBEE is potentially applicable in the U.S. market and offers the unique "BEE approach" to representing the performance evaluation data. Based on the information available, it would not be applicable to all of the GSA project types, specifically tenant build-out. The system requires documentation of quantifiable sustainable design achievements which are assessed by trained, first-class architects, which have passed the CASBEE assessor examination. Major modifications are 
expected to be made to the system every year; however the process for those revisions is unknown. Fewer than 10 buildings have used the system and all of those are in Japan, thus it is relatively unknown in the U.S. market.

- GBTool is an international system that has been used to evaluate U.S. buildings for the Green Building Challenge, including one GSA building. With respect to applicability to GSA project types, GBTool would be applicable for all but tenant build out and operations and maintenance applications; however, an operations and maintenance version is under development. A third party team establishes the qualitative and quantitative measures that are used to evaluate sustainable design achievements and expected building performance. The system has undergone 4 updates since its inception in 1998, which occur based on the experiences gained through its use. Due to the flexibility inherent in the application of GBTool, it tends to require greater technical expertise to implement than other rating systems, which has limited its exposure in the U.S. market.

- Green Globes ${ }^{\mathrm{TM}}$ US was adapted from Green Globes Canada in 2004 and is the newest system considered in this review. Currently, the U.S. version is not available for all of the GSA project types; however, Green Globes ${ }^{\mathrm{TM}}$ US is developing tools that address the major renovation, tenant build-out, and operations and maintenance applications. The Green Building Initiative received accreditation as a standards developer by ANSI and is working toward developing Green Globes ${ }^{\mathrm{TM}}$ US as an official ANSI standard. Currently, sustainable design and construction information is submitted on-line for thirdparty verification, which is provided by a Green Building Initiative-approved and Green Globes trained professional. According to feedback provided by the Green Building Initiative, 6 regional assessors were expected to be trained by June 2006. Following the completion of the ANSI process, it is expected the third party verification process will be revised. The Green Globes ${ }^{\mathrm{TM}}$ US rating system was not consistently available on-line during the review period and the current version of the on-line rating system tool is still not available and no date is given for its expected completion. Although there has been much publicity around Green Globes ${ }^{\mathrm{TM}}$ US in recent years, according to feedback provided by the Green Building Initiative, 4 buildings have received Green Globes ratings and 63 buildings have registered, which means they may potentially pursue verification in the future.

- $\quad$ LEED $^{\circledR}$ is currently the dominant system in the United States market and is being adapted to multiple markets worldwide. The currently available LEED $^{\circledR}$ rating systems address all of the GSA building and project types. A Product Development and Maintenance Manual is publicly available which governs how changes are made to the LEED $^{\circledR}$ rating systems. The steps followed for the development of U.S. Green Building Council rating system products include technical development by committee, pilot testing, public comment period, approval by council membership, and then release for public use. For the 
existing LEED $^{\circledR}$ rating systems, minor updates can occur no more than once a year, while major updates are expected to occur on a 3-5 year cycle, and will follow a defined process including a public comment period. Documentation of the quantifiable sustainable design measures are provided to the U.S. Green Building Council, the developer of the LEED $^{\circledR}$ rating system, for third-party verification. The assessors have been trained and must pass an assessor examination. More than 400 U.S. buildings have received LEED $^{\circledR}$ ratings and more than 3400 buildings are registered and therefore potentially seeking certification. LEED $^{\circledR}$ is not only the U.S. market leader, but is also the most widely use rating system by Federal and state agencies, which makes it easy to communicate a building's sustainable design achievements with others.

There are many resources available for incorporating sustainable design principles into a building life cycle. Sustainable building rating systems are used to examine the performance or expected performance of a 'whole building' and translate performance assessment into a tool that can be used to compare the building performance of other buildings or a performance standard. The information provided in this document offers comparative details on each of the rating systems using the review criteria developed from GSA and other Federal drivers. 


\section{Appendix A - References}

Note: Webpage addresses included in references were correct as of March 2006, unless otherwise noted.

AggRegain. BREEAM Offices. Waste \& Resources Action Programme (WRAP). Accessed February 2006a.

http://www.aggregain.org.uk/sustainability/examples_of tools_and_approaches/breeam $\underline{\text { index.html }}$

AggRegain. BREEAM Offices. Step 3: Credit Calculations. Accessed March 2006b. http://www.aggregain.org.uk/sustainability/examples_of tools_and_approaches/breeam breeam offices $3 . \mathrm{html}$

AggRegain. BREEAM Offices. Step 4: BREEAM Ratings. Accessed March 2006c. http://www.aggregain.org.uk/sustainability/examples of tools and approaches/breeam /breeam offices $4 . \mathrm{html}$

American Forest \& Paper Association (AF\&PA). Wood Products: Green Building. Accessed January 2006.

http://www.afandpa.org/Content/NavigationMenu/Wood_Products/Green_Building/Gr een_Building.htm

American Forest \& Paper Association. Green Building Fact Sheet: Wood and the Greening of Commercial and Residential Buildings. Accessed February 2006. http://www.afandpa.org/Content/NavigationMenu/Wood_Products/Green_Building/Gr een_building_Fact_Sheets/GBfact2.pdf

American Institute of Architects (AIA) Seattle Chapter. January 2006. Kudos \& Thanks: Weber + Thompson.

http://www.aiaseattle.org/notables and heroes.htm\#Kudos

American Institute of Architects (AIA). 2005. Green/High-Performance Building Resources. http://www.aia.org/adv_st_green highperformance

Annex 31. 2006. Assessment Framework and Rating: Ekoprofile. http://annex31.wiwi.uni-karlsruhe.de/MainFrame tools norway.htm

Annex 31. October 2001. Directory of Tools: A Survey of LCA Tools, Assessment Frameworks. Rating Systems, Technical Guidelines, Catalogues, Checklists and Certificates. http://annex31.wiwi.uni-karlsruhe.de/pdf/Microsoft $\% 20$ Word $\% 20$ \%20Annex $\% 2031 \% 20$ Directory $\% 20$ of $\% 20$ Tools $\% 20$ by $\% 20$ Country $\% 20$ and $\% 20$.pdf

ARUP. 2006. SPeAR ${ }^{\circledR}$ : Product overview.

http://www.arup.com/environment/feature.cfm?pageid=1685 
ATHENA $^{\text {TM }}$ Sustainable Materials Institute, ATHENA ${ }^{\text {TM }}$ Institute International. March 2002. US Federal and Military Applications of LEED: Lessons Learned.

http://www.athenasmi.ca/projects/leed/docs/LLL\%20Report.pdf

ATHENA $^{\text {TM }}$ Sustainable Materials Institute. September 2002. LEED Canada Adaptation and BREEAM/Green Leaf Harmonization Studies: Part I Project Summary and Overview Observations.

http://www.athenasmi.ca/projects/leed/docs/PartI_LEED_CanadaHarm.pdf

Australian Building Greenhouse Rating. 2004. http://www.abgr.com.au/new/default.asp

Australian Government: Department of the Environment and Heritage. March 17, 2006. Sustainable Construction. http://www.deh.gov.au/settlements/industry/construction/

Boecker, John, Joel Ann Todd, Ann Kosmal, “A Decade of Green Building Rating Systems: Lessons Learned”, presented at GreenBuild, Atlanta, GA, November 2005

Bowen, Ted S. November 4, 2005. Constructive criticism for green standards: LEED building program confronts critics and growing pains. http://www.msnbc.msn.com/id/9925473/from/RL.2/

Bespoke BREEAM. 2006. http://www.breeam.org/bespoke.html and http://www.breeam.org/pdf/Bespoke\%20Guidance\%20-\%20For\%20Clients_v1.1_.pdf

BREEAM: Building Research Establishment's Environmental Assessment Method. 2006. http://www.breeam.org/

Building Green Inc. March 2005. Green Globes Emerges to Challenge LEED. Environmental Building News. http://www.buildinggreen.com/auth/article.cfm?filename=140304b.xml

Building Research Establishment Ltd. (BRE Ltd.) Search for BREEAM Offices. Accessed February 2006. http://www.brebookshop.com/search.jsp

Canadian Standards Association. 2006. Building Materials and Structural Products Certification Program. http://www.csainternational.org/product_areas/building_and_structural/

CASBEE for New Construction Technical Manual, March 2004 Edition and Software CD 2004 Edition

CASBEE Web Site (in English). 2006. http://www.ibec.or.jp/CASBEE/english/

Cementation Foundations Skanska. May 16, 2005. M4I (Movement for Innovation). http://www.skanska.co.uk/skanska/templates/page.asp?id=2969 
Center for Sustainable Building Research (CSBR). 2005. The State of Minnesota Sustainable Building Guidelines (MSBG): Buildings, Benchmarks \& Beyond. College of Architecture and landscape Architecture - University of Minnesota. http://www.csbr.umn.edu/B3/index.html

Center for Sustainable Building Research. July 1, 2004. Print Version for the Minnesota Sustainable Building Guidelines Version 1.1. College of Architecture and Landscape Architecture - University of Minnesota. http://www.csbr.umn.edu:16080/B3/MSBG_v1_1.pdf

Central Point of Expertise on Timber Procurement (CPET). Accessed March 2006. http://www.proforest.net/cpet

City of Scottsdale, Arizona. 2006. Environment \& Preservation: Green Building Program. http://www.scottsdaleaz.gov/greenbuilding/default.asp?catID=5\&linkID=101\&lType=1

Cole, Raymond J. February 1, 2001. A Building Environmental Assessment Method for British Columbia. Environmental Research Group, School of Architecture University of British Columbia

Comprehensive Assessment System for Building Environmental Efficiency (CASBEE), Japan Sustainable Building Consortium brochure

CRISP Database available at http://www.crisp.cstb.fr

CSIR Building and Construction Technology Sustainable Buildings Group FPM. August 31, 2003. The Sustainable Building CD: Users Manual. http://www.sustainablebuildings.co.za/introduction/SB\%20manual.pdf

CSTB - Centre Scientifique et Technique du Bâtiment. 2006. Sustainable Development. http://international.cstb.fr/frame.asp?URL=research/default.asp

DeStefano, Jim. August 2005. Understanding Green Building Rating Systems. Structure Magazine.

http://www.structuremag.org/archives/2005/August\%202005/Understanding-GreenBuilding-Ratings.pdf

ECD Energy and Environment Canada Ltd. February 2002. LEED Canada Adaptation and BREEAM/Green Leaf Harmonization Studies: Part III BREEAM GREEN LEAF HARMONIZATION STUDY. http://www.athenasmi.ca/projects/leed/docs/Part_III_Harmoniz_Rpt.pdf

Energy and Resources Institute. November 24, 2005. TERI-GRIHA (TERI-Green Rating for Integrated Habitat Assessment). http://www.sustainablebuildings.org/files/TL54.pdf?PHPSESSID=3f99fa29b907568d3a2438e142a648ba 
Energy Star. September 27, 2005. Tools of Trade: ENERGY STAR Collaborates with the New Jersey Chapter of USGBC on Energy

Wokshop.https://www.energystar.gov/index.cfm?c=new_bldg_design.new_bldg_design news

Energy Tech. 2006. Ecobuilding - Building Optimisation with Total Quality (TQ) Assessment.

http://www.energytech.at/static/architektur/publikationen/results/id1772.html

Environment and Development Foundation (EDF). 2006. Greenmark Program. http://greenmark.epa.gov.tw/english/index.asp

Environmental Design+Construction (ED+C). November 7, 2005. GBI becomes ANSI accredited standards developer.

http://www.edcmag.com/CDA/Articles/Industry News/a0e1142e8e697010VgnVCM10 $\underline{0000 \mathrm{f} 932 \mathrm{a} 8 \mathrm{c} 0}$

Ervin, Christine. May 25, 2005. Pressure on LEED: Threat or Boon? Greener Buildings. http://www.greenerbuildings.com/news_detail.cfm?NewsID=28152

European Thematic Network on Construction and City Related Sustainability Indicators. 2006. CRISP Sustainable Construction Indicators Database.

http://crisp.cstb.fr/db_ListIS.asp

Executive Order 13101. Greening the Government through Waste Prevention, Recycling, and Federal Acquisition. http://www.wbdg.org/pdfs/eo13101.pdf

Executive Order 13123. Greening the Government through Efficient Energy Management. http://www.wbdg.org/pdfs/eo13123.pdf

FABER MAUNSELL. BREEAM: FAQ. Accessed March 2006.

http://www.fabermaunsell.com/Resources/40/87/index.jsp

Federation of Master Builders. January 22, 1999. Minister Unveils BREEAM '98. http://www.fmb.org.uk/publications/masterbuilder/november98/breeam.asp

Five Winds International. July 2004. Environmental Concepts and Tools: Green Building Design. http://www.fivewinds.com/uploadedfiles shared/GreenBuildingDesign040127.pdf

Forest Stewardship Council. 2006. http://www.fscus.org

Frangos, Alex. October 19, 2005. Is It Too Easy Being Green? Eco-Friendly Certification Is Big With Builders, Tenant; Critics See a 'Broken’ System. The Wall 
Street Journal Online. (members only)

http://online.wsj.com/article/SB112967950603172567.html

GBTool 1998, 2000, 2002, 2005 and applicable Manuals available at www.iisbe.org

Gibberd, Jeremy, et al. 2005. Assessing Sustainable Buildings in Developing Countries

- The Sustainable Building Assessment Tool (SBAT) and the Sustainable Building Life Cycle. SB05, Tokyo, Japan.

Gibberd, Jeremy. 2003. Developing a Sustainable Development Approach for Buildings and Construction Processes. CIB International Conference on Smart and Sustainable Built Environment.

Geissler, Susanne, and M. Bruck. Total Quality (TQ) Assessment as the Basis for Building Certification in Austria. http://www.argetq.at/zertifikat/materialien/tq oslo.pdf

Green Building Challenge (GBC). 1998. Conference Proceedings. Vancouver, British Columbia, Canada.

Green Building Council Australia. 2006. Green Star. http://www.gbcaus.org/greenstar/page.asp?id=117

Green Building Council Korea. 1999. Green Building Rating System. http://www.gbckorea.co.kr/eng-8.asp

Green Building Initiative (GBI). Accessed May 2006a. Energy \& Environmental Performance Assessment and Benchmarking of Buildings. Green Globes (GG) webcast. http://www.thegbi.org/greenglobes/pdf/webcast.pdf

GBI. Accessed March 2006b. Green Globes webpage. http://www.thegbi.com/greenglobes/

GBI. Accessed February 2006c. Not available as of February 24, 2006. Green Globes:Assessment and Rating System: Program Summary and Users Guide. http://www.thegbi.com/commercial/greenglobes/pdf/U.S.Summary-Final.pdf

Green Globes. 2006a. GEM UK - Environmental Assessment of Buildings. http://www.greenglobes.com/existing/homeuk.asp

Green Globes. 2006b. Green Globes USA, Green Globes Canada, GEM UK. http://www.greenglobes.com/

Herz, Johnathan. Public Architecture and LEED: Making It Green AND Fair. The American Institute of Architects. Accessed January 2006.

http://www.aia.org/pa_a 20041204_LEED 
HKBEAM Society. 2003. HK-BEAM: The Hong Kong Building Environmental Assessment Method. http://www.hk-beam.org.hk/general/home.php

Hong Kong (HK) Special Administration Region Government, Buildings Department. 2005. Comprehensive Environmental Performance Assessment System for Buildings: New Assessment Method for Building Sustainability in High Density Urban Context, Brochure distributed at SB05.

IEA-BCS Annex 31. February 19, 2002. Finland Energy certification for residential and office buildings. http://www.uni-weimar.de/scc/PRO/TOOLS/fin-certification.html

International Initiative for a Sustainable Built Environment. March 2004. Advanced Building News. http://greenbuilding.ca/ABNnews/ABN 02.pdf

Issaquah Highlands. 2006. Blakely Hall Receives Dual Green Certifications. http://www.issaquahhighlands.com/greenglobeaward2.html

James, Peter, and D. Somervell. April 29, 2004. Assessing the Environmental Performance of Buildings in Higher Education. Summary of a HEEPI workshop, University of Leicester.

http://www.heepi.org.uk/documents/Assessing\%20the\%20environmental\%20performa nce $\% 20$ of $\% 20$ Buildings $\% 20$ in $\% 20$ HE.doc

JSBC: Japan Sustainable Building Consortium. 2005. CASBEE: Comprehensive Assessment System for Building Environmental Efficiency. http://www.ibec.or.jp/CASBEE/english/index.htm

Labs 21. March, 7, 2006. Labs for the 21st century. http://www.labs21 century.gov/

Langer, Kenneth, and R. Watson. November 7, 2005. Bringing LEED to China. http://www.edcmag.com/CDA/Articles/Feature Article/5a10142e8e697010VgnVCM1 $\underline{00000 f 932 \mathrm{a} 8 \mathrm{c} 0}$

LEGEP $^{\circledR}$. 2006. LEGEP ${ }^{\circledR}$ : Tool for integrated lifecycle performance of buildings. http://www.legoe.de/index.php?AktivId=1125

Lewis, Malcolm, and H. Miranda. 2002. Impacts of a Green Building Rating System on the Design and Construction Process: A Summary of Ten Projects Using LEED ${ }^{\mathrm{TM}}$. http://www.sbis.info/docs/Conf/SB2002/Cities/001 lewis.pdf

Los Angeles Community Colleges (LACC). December 2, 2005. LACCD Project is First in U.S. to Receive BREEAM Certification. http://www.propositiona.org/newsroom/Awards/BREEAM_award_02dec05.htm 
Minnesota Sustainable Communities Network (MSCN), NextStep. October 13, 2005. Minnesota Sustainable Design Guide.

http://www.nextstep.state.mn.us/res detail.cfm?id=71

Memorandum of Understanding. January 2006. Federal Leadership in High

Performance and Sustainable Buildings Memorandum of Understanding.

http://www.wbdg.org/pdfs/sustainable mou.pdf

Murakami, Shuzo. January 20-23rd, 2003. Today's approach for promoting s approach for promoting sustainable building in Japan. http://www.asianforum.net/conference 2003/pdf/CASBEE Murakami AsianForum.pdf

National Associate of Home Builders (NAHB). 2006. NAHB's Model Green Home Building Guidelines.

http://www.nahb.org/fileUpload_details.aspx?contentTypeID=7\&contentID=1994

National Australian Built Environment Rating System (NABERS). 2006. NABERS Frequently Asked Questions. http://www.nabers.com.au/nabers/faq.htm

Natural Resources Canada. April 12, 2005. Buildings Group: C-2000 Program. http://www.buildingsgroup.nrcan.gc.ca/projects/c2000_e.html

O'Brian, Mary, and J. Nile. 2003. BUILDING BETTER BUILDINGS: The Transition to Environmental Building in Canada.

http://www.fes.uwaterloo.ca/ers/research/90sForWeb/ObrienNiles.pdf

Office of Management and Budget (OMB). 2002. "Section 55 - Energy and Transportation Efficiency Management." OMB Circular No. A-11

PEFC Council (Programme for the Endorsement of Forest Certification schemes). Accessed March 2006. http://www.pefc.org/internet/html/

Personal communication (PC) from representatives of GBTool. March 29 $9^{\text {th }}, 2006$.

Personal communication (PC) from representatives of the Green Building Initiative (GBI). April $5^{\text {th }}, 2006$.

Personal communication (PC) from representatives of the Institute for Building Environment and Energy Conservation (IBEC). April 14, 2006.

Personal communication (PC) from representatives of the U.S. Green Building Council (USGBC). April $5^{\text {th }}, 2006$.

Personal communication with Ilari Aho October 27, 2005. 
Provisional Construction Industry Co-ordination Board, Buildings Department. November 2005. Comprehensive Environmental Performance Assessment Scheme Paper No. PCICB/126. http://www.pcicb.gov.hk/eng/meeting/download/p-pcicb-126e.doc

Provisional Construction Industry Co-ordination Board. November, 2004. Comprehensive Environmental Performance Assessment Scheme.

Robert Lechner et al., Total Quality Building (TQB), The Austrian Building Assessment Tool, SB05, Tokyo

Scheuer, Chris W., and G.A. Keoleian. September 2002. Evaluation of LEED® Using Life Cycle Assessment Methods. Center for Sustainable Systems, University of Michigan. http://www.bfrl.nist.gov/oae/publications/gcrs/02836.pdf

Shendler, Auden, and R. Udall. October 27, 2005. LEED Is Broken; Let's Fix It. http://www.grist.org/comments/soapbox/2005/10/26/leed/index1.html

Shik Shin, Kee. Green Building Certification System in Korea, SB05, Tokyo

Solomon, Nancy B. How Is LEED Faring After Five Years in Use? Architectural Record: McGraw Hill Construction. Accessed March 2006. http://archrecord.construction.com/features/green/archives/0506edit-1.asp

Schwartz, Jerry. January 23, 2005. Steven Winter Associates, Inc. LEED ${ }^{\circledR}$ Cost Study: Final Report. Summarization. Prepared by AF\&PA.

Steven Winter Associates, Inc. October 2004. LEED ${ }^{\circledR}$ Cost Study: Final Report. http://www.getf.org/file/toolmanager/CustomO16C45F60590.pdf

Sustainable Buildings (SB). 2000. Conference Proceedings. Maastricht, The Netherlands.

Sustainable Building (SB). 2002. Conference Proceedings. Oslo, Norway.

Sustainable Building (SB). 2005. Conference Proceedings. Tokyo, Japan.

Sustainable Forestry Initiative. March 24, 2006. SFI ${ }^{\circledR}$ Labeling Program. http://64.29.218.149/sfilabel use.asp

Sustainable Forestry Initiative ${ }^{\circledR}$ (SFI). Where Can Interested Stakeholders Go for Accurate and Objective Information Comparing Forest certification programs? www.aboutsfi.org Provided by Jerry Schwartz, AF\&PA.

Sylviane Nibel, et al, ESCALE, Assessment Method of Buildings Environmental Performance, Sustainable Buildings 2000, Maastricht, Netherlands, October 2000 
Sylviane Nibel, et al., French Certification for Non-Residential "High Environmental Quality” Building Projects, SB05, Tokyo;

Tamm, Elanna. September 30, 2005. Green Building Products. United States Commercial Service. http://www.buyusainfo.net/docs/x 1251980.pdf

Technical Office for the Use of Steel (France). 2006. The HQE® (High Environmental Quality) programme. http://www.otua.org/expertises_sustainable development6.htm

Timo Rintala and Ilari Aho, PROMISE: Environmental Classification of Buildings: Current Situation and Objectives, June 25, 2003

Todd, Joel Ann, et al. 2001. "Comparative Assessment of Environmental Performance Tools and the Role of Green Building Challenge," Building Research and Information, (2001) 29(5), 324-335.

Transportation, Treasury, Housing and Urban Development, the Judiciary, the District of Columbia, and Independent Agencies Appropriations Act, 2006, Public Law 109115.

Trine Pettersen et al, Ecoprofile - a simplistic environmental assessment method: experiences and new challenges," SB2000, Oslo, Norway

U.S. Army Corp of Engineers, Department of the Army. May 1, 2001. Sustainable Design for Military Facilities. http://www.usace.army.mil/inet/usace-docs/eng-tech1trs/etl1110-3-491/entire.pdf

U.S. Army Engineer Research and Development Center. 2000. Sustainable Project Rating Tool (SPiRiT).

http://www.cecer.army.mil/earupdate/nlfiles/2000/sustainable2.cfm

U.S. Green Building Council (USGBC). 2006. U.S. Green Building Council. http://www.usgbc.org/

USGBC. October, 2005. LEED for New Construction and Major Renovation. http://www.usgbc.org/

USGBC. January, 2006. LEED Product Development and Maintenance Manual. https://www.usgbc.org/ShowFile.aspx?DocumentID=626

U.S. Environmental Protection Agency. Environmental Labeling Issues, Policies, and Practices Worldwide: Taiwan's Green Mark Program. http://www.epa.gov/oppt/epp/pubs/envlab/taiwan.pdf\# 
University of California Berkeley, Department of Architecture. 2006. Sustainability Resources for Further Information.

http://arch.ced.berkeley.edu/courses/arch249x_1_SP03/RatingResources.htm

University of Minnesota - College of Architecture and Landscape Architecture. 2001. Minnesota Sustainable Design Guide. http://www.sustainabledesignguide.umn.edu/

Walsh, Bill. August 9, 2005. Green Building Movement Shows Its True Colors: Highlights From The AIA Sustainability Summit. Healthy Building Network. http://www.healthybuilding.net/news/aia_true_colors-080905.html

Walsh, Bill. July 19, 2005. Conflicts of Interest at the American Institute of Architects: Trade Associations Set The Greenwash Agenda. Healthy Building Network. http://www.healthybuilding.net/news/aia-071905.html

Whole Building Design Guide (WBDG). 1999. "Letter to Beth Shearer regarding response to Executive Order 13123."

Whole Building Design Guide (WBDG), Sustainable Committee. March 2006.

Sustainable. http://www.wbdg.org/design/sustainable.php

World Green Building Council. 2006. http://www.worldgbc.org/?id=86 


\section{Appendix B - List of Sustainable Design and Operations Related Systems Pre-Screened from the Analysis}

\begin{tabular}{|c|c|c|c|}
\hline Sustainable Design Tools & Why Not Included & Sustainable Design Tools & Why Not Included \\
\hline Green Building Advisor (US) & Catalogue & $\begin{array}{l}\text { Environmental Profiles of } \\
\text { construction materials, } \\
\text { components and buildings (UK) }\end{array}$ & $\begin{array}{l}\text { Database of LCA } \\
\text { information }\end{array}$ \\
\hline Energy Star & Energy analysis & Quest & Policy choice tool \\
\hline $\begin{array}{l}\text { Energy Certification for } \\
\text { Buildings (Finland) }\end{array}$ & Energy analysis & $\begin{array}{l}\text { BM Bau Building Passport } \\
\text { (Germany) }\end{array}$ & $\begin{array}{l}\text { Product } \\
\text { specification guide }\end{array}$ \\
\hline BSEA 1.0 (Finland) & Energy Analysis & $\begin{array}{l}\text { The Movement for Innovation } \\
\text { (M4i) }\end{array}$ & $\begin{array}{l}\text { Construction \& } \\
\text { Design Safety }\end{array}$ \\
\hline $\begin{array}{l}\text { NEN 2916/5128, NPR } \\
2917 / 5129 \text { (Netherlands) }\end{array}$ & $\begin{array}{l}\text { Energy Modeling } \\
\text { Software }\end{array}$ & EcoProP & $\begin{array}{l}\text { Requirements } \\
\text { management system }\end{array}$ \\
\hline SIMBAD (Finland) & $\begin{array}{l}\text { Energy Modeling } \\
\text { Software }\end{array}$ & Costing Reference Model & Residential \\
\hline EDIP (Denmark) & $\begin{array}{l}\text { Environmental } \\
\text { assessment of products }\end{array}$ & $\begin{array}{l}\text { Super E House Program } \\
\text { (Canada) }\end{array}$ & Residential \\
\hline $\begin{array}{l}\text { Environmental Classification of } \\
\text { Properties }\end{array}$ & $\begin{array}{l}\text { Environmental impact } \\
\text { assessment }\end{array}$ & AccuRate (Australia) & Residential \\
\hline Papoose (Finland) & $\begin{array}{l}\text { Environmental impact } \\
\text { assessment }\end{array}$ & Alameda County (CA) & Residential \\
\hline Envest & $\begin{array}{l}\text { Environmental impact } \\
\text { assessment tool }\end{array}$ & $\begin{array}{l}\text { BASIX Building Sustainability } \\
\text { Index (Australia) }\end{array}$ & Residential \\
\hline EcoEffect (Sweden) & $\begin{array}{l}\text { Environmental Impact } \\
\text { Software model }\end{array}$ & BERS (Australia) & Residential \\
\hline ISO 14001 & $\begin{array}{l}\text { Environmental } \\
\text { Management System }\end{array}$ & $\begin{array}{l}\text { Build a Better Clark (Clark } \\
\text { County Washington HBA) }\end{array}$ & Residential \\
\hline MRPI Netherlands & $\begin{array}{l}\text { Environmental product } \\
\text { declaration }\end{array}$ & $\begin{array}{l}\text { Build A Better Kitsap Home } \\
\text { Builder Program (Kitsap, WA } \\
\text { HBA) }\end{array}$ & Residential \\
\hline $\begin{array}{l}\text { Cities for Climate Protection } \\
\text { Software }\end{array}$ & $\begin{array}{l}\text { GHG emissions } \\
\text { inventories tool }\end{array}$ & $\begin{array}{l}\text { National Association of Home } \\
\text { Buildings (NAHB) Green } \\
\text { Guidelines }\end{array}$ & Residential \\
\hline $\begin{array}{l}\text { City of Santa Monica Green } \\
\text { Building \& Construction } \\
\text { Guidelines }\end{array}$ & Guideline & Built Green Alberta (Canada) & Residential \\
\hline ECDG - Japan & Guideline & $\begin{array}{l}\text { Built GreenTM (MBA of King } \\
\text { and Snohomish Counties, WA) }\end{array}$ & Residential \\
\hline $\begin{array}{l}\text { Green Building Program (Austin, } \\
\text { TX) }\end{array}$ & Guideline & $\begin{array}{l}\text { Built GreenTM Colorado (HBA } \\
\text { of Metro Denver) }\end{array}$ & Residential \\
\hline $\begin{array}{l}\text { National Packages Sustainable } \\
\text { Building (Netherlands) }\end{array}$ & Guideline & $\begin{array}{l}\text { California Green Builder } \\
\text { Program }\end{array}$ & Residential \\
\hline $\begin{array}{l}\text { NYC High Performance } \\
\text { Building Guidelines }\end{array}$ & Guideline & $\begin{array}{l}\text { Chula Vista (CA) GreenStar } \\
\text { Building Incentive Program }\end{array}$ & Residential \\
\hline $\begin{array}{l}\text { Seattle Sustainable Building } \\
\text { Action Plan and Built Smart } \\
\text { (Seattle, WA) }\end{array}$ & Guideline & $\begin{array}{l}\text { City of Boulder Green Points } \\
\text { (CO) }\end{array}$ & Residential \\
\hline $\begin{array}{l}\text { Tokyo Metro Green Building } \\
\text { Program }\end{array}$ & Guideline & $\begin{array}{l}\text { City of Frisco (TX) Green } \\
\text { Building Program }\end{array}$ & Residential \\
\hline
\end{tabular}




\begin{tabular}{|c|c|c|c|}
\hline Sustainable Design Tools & Why Not Included & Sustainable Design Tools & Why Not Included \\
\hline "Green" Hotels Association (US) & Hotels/Lodging & $\begin{array}{l}\text { County of Santa Barbara } \\
\text { Innovative Building Review } \\
\text { Program (CA) }\end{array}$ & Residential \\
\hline $\begin{array}{l}\text { Coalition for Environmentally } \\
\text { Responsible Economies } \\
\text { (CERES) Green Hotel Initiative } \\
\text { (US) }\end{array}$ & Hotels/Lodging & Earth Advantage Home (US) & Residential \\
\hline Green Globe 21 (US) & Hotels/Lodging & $\begin{array}{l}\text { Earth Advantage Program } \\
\text { (Portland General Electric) }\end{array}$ & Residential \\
\hline $\begin{array}{l}\text { Green Leaf Eco-Rating Program } \\
\text { (Canada) }\end{array}$ & Hotels/Lodging & $\begin{array}{l}\text { EarthCraft House (Greater } \\
\text { Atlanta, GA HBA) }\end{array}$ & Residential \\
\hline Green Rating Program (Africa) & Hotels/Lodging & EarthCraft House (US) & Residential \\
\hline Green Seal Certification (US) & Hotels/Lodging & EcoHomes (UK) & Residential \\
\hline $\begin{array}{l}\text { HVS International ECOTEL } \\
\text { Certification }\end{array}$ & Hotels/Lodging & $\begin{array}{l}\text { EnerGuide Houses Program } \\
\text { (Canada) }\end{array}$ & Residential \\
\hline $\begin{array}{l}\text { Sustainable Ecotourism Rating } \\
\text { (Costa Rica) }\end{array}$ & Hotels/Lodging & $\begin{array}{l}\text { Energy Rated Homes of } \\
\text { Colorado }\end{array}$ & Residential \\
\hline $\begin{array}{l}\text { Vermont Green Hotels in the } \\
\text { Green Mountain State }\end{array}$ & Hotels/Lodging & Energy Star (US, Canada) & Residential \\
\hline $\begin{array}{l}\text { Green Rating Initiative } \\
\text { (Ethiopia) }\end{array}$ & Industrial & $\begin{array}{l}\text { Evergreen Building Guide } \\
\text { (Issaquah, WA) }\end{array}$ & Residential \\
\hline Green Rating of Indian Industry & Industrial & FirstRate (Australia) & Residential \\
\hline $\begin{array}{l}\text { Sustainable Project Appraisal } \\
\text { Routine (SPEAR) }\end{array}$ & Industrial & G/Rated (Portland, OR) & Residential \\
\hline Global Reporting Initiative & Industrial Reporting & $\begin{array}{l}\text { Green Building Program, Austin } \\
\text { Energy (TX) }\end{array}$ & Residential \\
\hline BEAT 2000 (Denmark) & $\begin{array}{l}\text { Life Cycle assessment } \\
\text { tool }\end{array}$ & $\begin{array}{l}\text { Green Built Home (Wisconsin } \\
\text { Environmental Initiative) }\end{array}$ & Residential \\
\hline BRI LCA (Japan) & $\begin{array}{l}\text { Life Cycle assessment } \\
\text { tool }\end{array}$ & $\begin{array}{l}\text { Green Built Program (HBA of } \\
\text { Greater Grand Rapids, MI) }\end{array}$ & Residential \\
\hline EcoIndicator (Netherlands) & $\begin{array}{l}\text { Life Cycle assessment } \\
\text { tool }\end{array}$ & $\begin{array}{l}\text { Green Home Designation } \\
\text { (Florida Green Building } \\
\text { Coalition) }\end{array}$ & Residential \\
\hline EcoInstall (Netherlands) & $\begin{array}{l}\text { Life Cycle assessment } \\
\text { tool }\end{array}$ & $\begin{array}{l}\text { Green Points Building Program } \\
\text { (Boulder, CO) }\end{array}$ & Residential \\
\hline EcoPro (Germany) & $\begin{array}{l}\text { Life Cycle assessment } \\
\text { tool }\end{array}$ & Hawaii BuiltGreenTM & Residential \\
\hline EcoQuantum (Netherlands) & $\begin{array}{l}\text { Life Cycle assessment } \\
\text { tool }\end{array}$ & $\begin{array}{l}\text { Health House Advantage } \\
\text { Certification (US) }\end{array}$ & Residential \\
\hline LCA-House (Finland) & $\begin{array}{l}\text { Life Cycle assessment } \\
\text { tool }\end{array}$ & HERS (US) & Residential \\
\hline LCAiT (Sweden) & $\begin{array}{l}\text { Life Cycle assessment } \\
\text { tool }\end{array}$ & $\begin{array}{l}\text { Home Builders Association of } \\
\text { Greater Kansas City (MO) }\end{array}$ & Residential \\
\hline Legoe (Germany) & $\begin{array}{l}\text { Life Cycle assessment } \\
\text { tool }\end{array}$ & HomeRun (Canada) & Residential \\
\hline OGIP (Switzerland) & $\begin{array}{l}\text { Life Cycle assessment } \\
\text { tool }\end{array}$ & $\begin{array}{l}\text { Hudson Valley HBA Green } \\
\text { Building Program (NY) }\end{array}$ & Residential \\
\hline REGENERS (Finland) & $\begin{array}{l}\text { Life Cycle assessment } \\
\text { tool }\end{array}$ & $\begin{array}{l}\text { Multifamily Green Building } \\
\text { Guidelines (Alameda County, } \\
\text { CA) }\end{array}$ & Residential \\
\hline
\end{tabular}




\begin{tabular}{|c|c|c|c|}
\hline Sustainable Design Tools & Why Not Included & Sustainable Design Tools & Why Not Included \\
\hline TAKE-LCA (Finland) & $\begin{array}{l}\text { Life Cycle assessment } \\
\text { tool }\end{array}$ & NatHERS (Australia) & Residential \\
\hline TEAM (Finland) & $\begin{array}{l}\text { Life Cycle assessment } \\
\text { tool }\end{array}$ & $\begin{array}{l}\text { New Mexico Building America } \\
\text { Partner Program (HBA of } \\
\text { Central New Mexico) }\end{array}$ & Residential \\
\hline Athena Model (Canada) & $\begin{array}{l}\text { Life Cycle assessment } \\
\text { tool }\end{array}$ & Novoclimat (Quebec, Canada) & Residential \\
\hline BEES (US) & $\begin{array}{l}\text { Life Cycle assessment } \\
\text { tool }\end{array}$ & R-2000 (Canada) & Residential \\
\hline $\mathrm{GaBi} 4$ & $\begin{array}{l}\text { Life Cycle assessment } \\
\text { tool }\end{array}$ & $\begin{array}{l}\text { Schenectady HBA Green } \\
\text { Building Program (NY) }\end{array}$ & Residential \\
\hline KCL-ECO & $\begin{array}{l}\text { Life Cycle assessment } \\
\text { tool }\end{array}$ & SeaGreen (Seattle) & Residential \\
\hline LISA (Austrailia) & $\begin{array}{l}\text { Life Cycle assessment } \\
\text { tool }\end{array}$ & $\begin{array}{l}\text { Southern Arizona Green } \\
\text { Building Alliance }\end{array}$ & Residential \\
\hline Umberto & $\begin{array}{l}\text { Life Cycle assessment } \\
\text { tool }\end{array}$ & $\begin{array}{l}\text { Super E House Program } \\
\text { (Canada) }\end{array}$ & Residential \\
\hline Solution Spaces (Canada) & $\begin{array}{l}\text { Life cycle cost and impact } \\
\text { of urban development } \\
\text { forecasting tool }\end{array}$ & $\begin{array}{l}\text { Super Good Cents and Natural } \\
\text { Choice Homes }\end{array}$ & Residential \\
\hline Equer (France) & Life Cycle simulation tool & $\begin{array}{l}\text { The BREEAM Green Leaf for } \\
\text { Multi-Residential Buildings } \\
\text { (Canada) }\end{array}$ & Residential \\
\hline Environmental Choice Program & $\begin{array}{l}\text { Materials assessment } \\
\text { method }\end{array}$ & $\begin{array}{l}\text { The Green Builder Program } \\
\text { (NM) }\end{array}$ & Residential \\
\hline MMG (Netherlands) & $\begin{array}{l}\text { Materials assessment } \\
\text { method }\end{array}$ & Vermont Built Green & Residential \\
\hline SIA 493 (Switzerland) & Materials checklist & $\begin{array}{l}\text { Western North Carolina Green } \\
\text { Building Council }\end{array}$ & Residential \\
\hline
\end{tabular}




\section{Appendix C - Additional Rating System Review Data}

The WBDG is the portal to "up-to-date information on integrated 'whole building' design techniques and technologies." In response to Executive Order 13123, sustainable design principles were developed by GSA, DOD, and other Federal agencies and were provided on the WBDG Sustainability webpage. In addition to the sustainability principles provided on this webpage, general design recommendations are also included on these pages. These recommendations offer ideas and comprehensive guidance on how to implement the sustainable design principles:

- Optimize Site Potential

- Optimize Energy Use

- Protect and Conserve Water

- Use Environmentally Preferable Products

- Enhance Indoor Environmental Quality (IEQ)

- Optimize Operational and Maintenance Practices

For each of these principles there is a list of actions that could be taken to address the principle. These previously endorsed recommendations were used as a tool to compare some of the rating systems' technical information. In this appendix the WBDG sustainable design principles and subsequent recommendations are being used for a comparison of how each rating system addressed these items. In the interest of brevity, only half of the principles were selected for this comparison: optimize energy use, use environmentally preferable products, and enhance indoor environmental quality. Optimizing energy use is a primary interest for GSA because increased energy efficiency helps GSA meet its energy use reduction goals and reduces operating costs. The use of environmentally preferable products is important to GSA because of its interest in minimizing its life cycle environmental impact. Enhancing indoor environmental quality is important to GSA because of its interest in providing high quality work environments for Federal workers.

The following key is provided to be used in conjunction with the tables in this appendix.

* These WBDG categories are covered by a credit whose points have been designated to another category.

$* *$ Credit C. 3 is an alternate Path B for buildings $\leq 20,000 \mathrm{ft} 2$. The amount of points achievable is 110 .

*** The heading for section $\mathrm{E}$ designates this section at 100 points. The actual addition of all categories was 102 points. The percentage calculations were calculated using the total of 102 points.

**** Weights in GBTool are established by third party assessment authority. 


\begin{tabular}{|c|c|c|c|c|c|c|c|c|c|c|c|c|c|c|}
\hline \multirow[b]{2}{*}{$\begin{array}{l}\text { WBDG Criteria for Optimize } \\
\text { Energy Use } \\
\end{array}$} & \multicolumn{3}{|l|}{ BREEAM } & \multicolumn{3}{|l|}{ CASBEE } & \multicolumn{2}{|l|}{ GBTool } & \multicolumn{3}{|l|}{ Green Globes } & \multicolumn{3}{|l|}{ LEED } \\
\hline & Energy & & $\begin{array}{l}\% \text { of } \\
\text { total }\end{array}$ & Energy & 92.5 & $\begin{array}{l}\% \text { of } \\
\text { total }\end{array}$ & $\begin{array}{l}\text { Energy and Resource } \\
\text { Consumption }\end{array}$ & 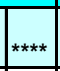 & Energy & 360 & $\begin{array}{l}\% \text { of } \\
\text { total }\end{array}$ & Energy and Atmosphere & $17]^{9}$ & $\begin{array}{l}\% \text { of } \\
\text { total }\end{array}$ \\
\hline $\begin{array}{l}\text { Reduce Heating, Cooling, and } \\
\text { Lighting Loads through Climate- } \\
\text { Responsive Design and } \\
\text { Conservation Practices } \\
\end{array}$ & $\begin{array}{l}\text { Losses minus gains } \mathrm{kWh} / \mathrm{m}^{2} \\
\text { (predicted according to the } \\
\text { fabric and form of the } \\
\text { building) }\end{array}$ & 40 & $50 \%$ & $\begin{array}{l}\text { Natural energy utilization } \\
\text { and Building thermal load }\end{array}$ & 25 & & $\begin{array}{l}\text { Lot orientation to maximize } \\
\text { passive solar potential and } \\
\text { Predicted non-renewable } \\
\text { energy used for building } \\
\text { operations }\end{array}$ & & C.1 - Energy Consumption & 110 & $31 \%$ & \begin{tabular}{|l|} 
EA Prerequisite 2- \\
Minimum Energy \\
Performance * \\
EA Credit 1 - Optimize \\
Energy Performance \\
EQ Credit 7 - Thermal \\
Comfort * \\
EQ Credit 1 - Outdoor Air \\
Delivery Monitoring * \\
\end{tabular} & 10 & $59 \%$ \\
\hline $\begin{array}{l}\text { Employ Renewable or High- } \\
\text { Efficiency Energy Sources }\end{array}$ & $\begin{array}{l}\text { At least } 10 \% \text { of either heat } \\
\text { demand or electricy } \\
\text { consumption in the building } \\
\text { is supplied from local } \\
\text { renewable energy sources } \\
\end{array}$ & 12 & $15 \%$ & Natural energy utilization & 10 & & $\begin{array}{l}\text { Assessment of Renewables } \\
\text { Feasibility and Plans for use } \\
\text { of on-site renewable energy } \\
\text { sources and Plans for use of } \\
\text { off-site energy that is } \\
\text { generated from renewable } \\
\text { sources }\end{array}$ & & $\begin{array}{l}\text { C. } 4 \text { - Renewable Energy } \\
\text { Sources }\end{array}$ & 45 & $13 \%$ & $\begin{array}{l}\text { EA Credit } 2 \text { - On-site } \\
\text { Renewable Energy } \\
\text { EA Credit } 6 \text { - Green Power }\end{array}$ & 4 & $24 \%$ \\
\hline $\begin{array}{l}\text { Specify Efficient HVAC and } \\
\text { Lighting Systems }\end{array}$ & \begin{tabular}{|l|} 
External light design is in \\
compliance with ILE \\
guidance notes for reduction \\
of light pollution.
\end{tabular} & 12 & $15 \%$ & $\begin{array}{l}\text { HVAC system and Lighting } \\
\text { system }\end{array}$ & 22.5 & $24 \%$ & & & \begin{tabular}{|l|} 
C.3 - Integration of Energy \\
Efficient Systems (alternate \\
Path B for buildings $\leq$ \\
$20,000 \mathrm{ft}^{2}$ ) \\
\end{tabular} & ** & ** & $\begin{array}{l}\text { EA Credit } 1 \text { - Optimize } \\
\text { Energy Performance }\end{array}$ & * & * \\
\hline $\begin{array}{l}\text { Optimize Building Performance } \\
\text { and System Control Strategies }\end{array}$ & & & & $\begin{array}{l}\text { Building thermal load and } \\
\text { operational management } \\
\text { system }\end{array}$ & 25 & & \begin{tabular}{|l|} 
Predicted non-renewable \\
primary energy used for \\
building operations and \\
Predicted electrical peak \\
demand for building \\
operations and Provision of \\
building management \\
control system and \\
Designed capability for \\
partial operation of building \\
technical systems \\
\end{tabular} & & $\begin{array}{l}\text { C. } 1 \text { Energy Consumption } \\
\text { OR } \\
\text { C. } 3 \text { "Right-sized" energy- } \\
\text { efficient systems }\end{array}$ & * & * & $\begin{array}{l}\text { EA Credit } 1 \text { - Optimize } \\
\text { Energy Performance * } \\
\text { EA Credit } 5-\text { M\&V }\end{array}$ & & $6 \%$ \\
\hline Monitor Project Performance & $\begin{array}{l}\text { Electrical sub metering for } \\
\text { major consuming items. } \\
\text { Electrical sub metering of } \\
\text { tenancy areas. } \\
\end{array}$ & 16 & $20 \%$ & $\begin{array}{l}\text { Monitoring and operational } \\
\text { management system }\end{array}$ & 10 & $11 \%$ & $\begin{array}{l}\text { Measures planned for on- } \\
\text { going monitoring and } \\
\text { verification of performance }\end{array}$ & & $\begin{array}{l}\text { C.2 - Energy Demand } \\
\text { Minimization } \\
\end{array}$ & 135 & $38 \%$ & $\begin{array}{l}\text { EA Credit } 5 \mathrm{M} \& V^{*} \\
\text { EA Credit } 3 \text { Enhanced } \\
\text { Commissioning }\end{array}$ & & $6 \%$ \\
\hline & & & & & & & & & $\begin{array}{l}\text { C. } 5 \text { - Energy Efficient } \\
\text { Transportation }\end{array}$ & 70 & $19 \%$ & \begin{tabular}{|l|} 
EA Prerequisite 3- \\
Fundamental Refrigerant \\
Management \\
EA Credit 4 - Enhanced \\
Refrigerant Management
\end{tabular} & 1 & $6 \%$ \\
\hline
\end{tabular}




\begin{tabular}{|c|c|c|c|c|c|c|c|c|c|c|c|c|c|c|}
\hline \multirow[b]{2}{*}{$\begin{array}{l}\text { WBDG Criteria for Enhance Indoor } \\
\text { Environmental Quality (IEQ) }\end{array}$} & \multicolumn{3}{|l|}{ BREEAM } & \multicolumn{3}{|l|}{ CASBEE } & \multicolumn{2}{|l|}{ GBTool } & \multicolumn{3}{|c|}{ Green Globes v.1 } & \multicolumn{3}{|l|}{ LEED } \\
\hline & Health \& Wellbeing & 150 & $\begin{array}{l}\% \text { of } \\
\text { total }\end{array}$ & Indoor Environment & 101 & $\begin{array}{l}\% \text { of } \\
\text { total }\end{array}$ & $\begin{array}{l}\text { Indoor environmental } \\
\text { quality }\end{array}$ & 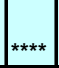 & Indoor Environment & 200 & $\begin{array}{l}\% \text { of } \\
\text { total }\end{array}$ & $\begin{array}{l}\text { Indoor Environmental } \\
\text { Quality }\end{array}$ & & $\begin{array}{l}\% \text { of } \\
\text { total }\end{array}$ \\
\hline $\begin{array}{l}\text { Facilitate Quality IEQ through } \\
\text { Good Design, Construction, and } \\
\text { O\&M Practices }\end{array}$ & $\begin{array}{l}\text { Ease of cleaning, } \\
\text { maintenance and } \\
\text { replacement of cooling } \\
\text { towers/evaporative } \\
\text { condensers }\end{array}$ & 10 & $7 \%$ & Source control & 6.3 & $6 \%$ & $\begin{array}{l}\text { Indoor air quality - finishes, } \\
\text { limit pollutant migration, } \\
\text { maintenance, etc. }\end{array}$ & & & & & $\begin{array}{l}\text { EQ Prerequisite } 1 \text { - Minimum } \\
\text { IAQ Performance } \\
\text { EQ Credit } 1 \text { - Outdoor Air } \\
\text { Delivery Monitoring } \\
\text { EQ Credit } 3 \text { - Construction IAQ } \\
\text { Management Plan }\end{array}$ & 3 & $20 \%$ \\
\hline Value Aesthetic Decisions & $\begin{array}{l}\text { Occupant distance to view } \\
\text { out of window }\end{array}$ & 10 & $7 \%$ & $\begin{array}{l}\text { Perceived spaciousness } \\
\text { and access to views }\end{array}$ & 4 & $4 \%$ & $\begin{array}{l}\text { Social aspects - views, } \\
\text { privacy }\end{array}$ & & $\begin{array}{l}\text { G.3 - Lighting design and } \\
\text { integration of lighting } \\
\text { systems }\end{array}$ & 45 & $23 \%$ & $\begin{array}{l}\text { EQ Credit } 8 \text { - Daylighting and } \\
\text { Views }\end{array}$ & 2 & $13 \%$ \\
\hline Provide Thermal Comfort & \begin{tabular}{|l|} 
Ventilation criteria met. \\
Local control of office area. \\
Thermal comfort levels used \\
in servicing efforts. \\
\end{tabular} & 30 & $20 \%$ & Thermal comfort & 35 & $34 \%$ & $\begin{array}{l}\text { Air temperature and relative } \\
\text { humidity }\end{array}$ & & G.4 - Thermal Comfort & 25 & $13 \%$ & $\begin{array}{l}\text { EQ Credit } 6.2 \text { - Controllability } \\
\text { of Systems - Thermal } \\
\text { EQ Credit } 7 \text { - Thermal Comfort }\end{array}$ & 3 & $20 \%$ \\
\hline $\begin{array}{l}\text { Supply Adequate Levels of } \\
\text { Ventilation and Outside Air }\end{array}$ & $\begin{array}{l}\text { Adequate cross ventilation is } \\
\text { promoted. }\end{array}$ & 10 & $7 \%$ & Ventilation & 7.5 & $7 \%$ & Ventilation & & $\begin{array}{l}\text { G.1 - Effective Ventilation } \\
\text { System }\end{array}$ & 60 & $30 \%$ & $\begin{array}{l}\text { EQ Credit } 2 \text { - Increased } \\
\text { Ventilation } \\
\text { EQ Credit } 5 \text { - Indoor Chemical } \\
\text { \& Pollutant Source Control } \\
\end{array}$ & 2 & $13 \%$ \\
\hline $\begin{array}{l}\text { Prevent Airborne Bacteria, Mold, } \\
\text { and Other Fungi }\end{array}$ & $\begin{array}{l}\text { Steam humidification is } \\
\text { installed, or no } \\
\text { humidification is present. }\end{array}$ & 10 & $7 \%$ & Control of mites and mold & 3.1 & $3 \%$ & $\begin{array}{l}\text { Humidity and limit pollutant } \\
\text { migration }\end{array}$ & & $\begin{array}{l}\text { G.2 - Source Control of } \\
\text { Indoor Pollutants }\end{array}$ & 45 & $23 \%$ & & & \\
\hline Limit Spread of Pathogens & \begin{tabular}{|l|} 
Minimize risk of \\
Legionellosis in hot and cold \\
water systems
\end{tabular} & 10 & $7 \%$ & & & & Limit pollutant migration & & & & & $\begin{array}{l}\text { EQ Prerequisite 2- } \\
\text { Environmental Tobacco } \\
\text { Smoke Control }\end{array}$ & & \\
\hline $\begin{array}{l}\text { Avoid the Use of Materials High in } \\
\text { Pollutants }\end{array}$ & & & & Chemical pollutants & 3.1 & $3 \%$ & $\begin{array}{l}\text { Selection of finishes, } \\
\text { materials }\end{array}$ & & $\begin{array}{l}\text { G.2 - Control of Indoor } \\
\text { Pollutants }\end{array}$ & * & * & \begin{tabular}{|l|} 
EQ Credit 4 - Low-Emitting \\
Materials
\end{tabular} & 4 & $27 \%$ \\
\hline $\begin{array}{l}\text { Assure Acoustic Privacy and } \\
\text { Comfort }\end{array}$ & $\begin{array}{l}\text { Ambient internal noise levels } \\
\text { specified }\end{array}$ & 10 & $7 \%$ & Noise and acoustics & 15 & $15 \%$ & Noise and acoustics & & G.5 - Acoustic Comfort & 25 & $13 \%$ & & & \\
\hline $\begin{array}{l}\text { Control Disturbing Odors through } \\
\text { Contaminant Isolation and } \\
\text { Product Selection }\end{array}$ & \begin{tabular}{|l|} 
Air intake serving occupied \\
areas avoid major sources \\
of external pollution
\end{tabular} & 10 & $7 \%$ & $\begin{array}{l}\text { Ventilation and control of } \\
\text { smoking }\end{array}$ & 2.5 & $2 \%$ & Limit pollutant migration & & $\begin{array}{l}\text { G.2 - Source Control of } \\
\text { Indoor Pollutants }\end{array}$ & * & * & & & \\
\hline $\begin{array}{l}\text { Create a High-Performance } \\
\text { Luminous Environment }\end{array}$ & $\begin{array}{l}\text { High frequency ballasts. } \\
\text { Lighting design compliance } \\
\text { to guide. } \\
\text { Occupant controlled glare } \\
\text { control. } \\
\text { Daylighting. } \\
\text { Lighting Zones }<4 \\
\text { workplaces. } \\
\end{array}$ & 50 & $33 \%$ & Lighting and illumination & 25 & $25 \%$ & Daylighting and illumination & & $\begin{array}{l}\text { G.3 - Lighting design and } \\
\text { integration of lighting } \\
\text { systems }\end{array}$ & * & * & $\begin{array}{l}\text { EQ Credit } 6.1 \text { - Controllability } \\
\text { of Systems - Lighting }\end{array}$ & 1 & $7 \%$ \\
\hline Provide Quality Water & & & & & & & & & & & & & & \\
\hline $\begin{array}{l}\text { Be Aware of Exposure to Electric } \\
\text { and Magnetic Fields (EMF) }\end{array}$ & & & & & & & & & & & & & & \\
\hline $\begin{array}{l}\text { Balance IEQ Strategies with } \\
\text { Security Requirements }\end{array}$ & & & & & & & & & & & & & & \\
\hline
\end{tabular}




\begin{tabular}{|c|c|c|c|c|c|c|c|c|c|c|c|c|c|c|}
\hline \multirow[b]{2}{*}{$\begin{array}{l}\text { WBDG Criteria for Use of } \\
\text { Environmentally Preferable } \\
\text { Products }\end{array}$} & \multicolumn{3}{|l|}{ BREEAM } & \multicolumn{3}{|l|}{ CASBEE } & \multicolumn{2}{|l|}{ GBTool } & \multicolumn{3}{|l|}{ Green Globes } & \multicolumn{3}{|l|}{ LEED } \\
\hline & Materials & 98 & $\begin{array}{l}\% \text { of } \\
\text { total }\end{array}$ & Resources and Materials & 85.85 & $\begin{array}{l}\text { \% of } \\
\text { total }\end{array}$ & Materials & 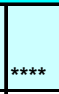 & \begin{tabular}{|l|} 
Resources, Building \\
Materials and Solid Waste \\
$\star \star \star \star$
\end{tabular} & 102 & $\begin{array}{l}\% \text { of } \\
\text { total }\end{array}$ & Materials \& Resources & & $\begin{array}{l}\% \text { of } \\
\text { total }\end{array}$ \\
\hline $\begin{array}{l}\text { Renovate Existing Facilities, } \\
\text { Products, and Equipment }\end{array}$ & $\begin{array}{l}\text { Reuse of the existing } \\
\text { structure. }\end{array}$ & 8 & & $\begin{array}{l}\text { Reuse existing building } \\
\text { structure and reuse } \\
\text { efficiency of materials in } \\
\text { structure }\end{array}$ & 15.3 & $18 \%$ & $\begin{array}{l}\text { Planned reuse of existing } \\
\text { structures, planned reuse of } \\
\text { salvaged materials }\end{array}$ & & $\begin{array}{l}\text { E.3 Reuse of existing } \\
\text { structures }\end{array}$ & 10 & $10 \%$ & $\begin{array}{l}\text { MR Credit } 1 \text { - Building Reuse } \\
\text { MR Credit } 3 \text { - Resource } \\
\text { Reuse }\end{array}$ & 5 & $38 \%$ \\
\hline $\begin{array}{l}\text { Evaluate Environmental } \\
\text { Preferability Using LCA }\end{array}$ & & & & & & $0 \%$ & & & $\begin{array}{l}\text { E.1 Materials with low } \\
\text { impact environmental impact }\end{array}$ & 40 & $39 \%$ & & & \\
\hline $\begin{array}{l}\text { Maximize the Recycled Content of } \\
\text { All New Materials }\end{array}$ & $\begin{array}{l}\text { Use of recycled façade, } \\
\text { aggregate or masonry } \\
\text { materials. }\end{array}$ & 16 & $16 \%$ & Recycled Materials & 29.75 & $35 \%$ & $\begin{array}{l}\text { Planned use of recycled } \\
\text { materials from off-site } \\
\text { sources }\end{array}$ & & \begin{tabular}{|l|} 
E.2 Minimized consumption \\
and depletion of material \\
resources
\end{tabular} & 30 & $29 \%$ & $\begin{array}{l}\text { MR Credit } 4 \text { - Recycled } \\
\text { Content }\end{array}$ & 2 & $15 \%$ \\
\hline $\begin{array}{l}\text { Specify Materials Harvested on a } \\
\text { Sustained Yield Basis }\end{array}$ & \begin{tabular}{|l|} 
Timber and composite \\
timber products are \\
specified from sustainably \\
managed sources or are \\
reused or recycled timber.
\end{tabular} & 18 & $18 \%$ & $\begin{array}{l}\text { Timber from sustainable } \\
\text { forests }\end{array}$ & 3.4 & $4 \%$ & $\begin{array}{l}\text { Planned use of bio-based } \\
\text { products obtained from } \\
\text { sustainable sources }\end{array}$ & & $\begin{array}{l}\text { E.2 Minimized consumption } \\
\text { and depletion of material } \\
\text { resources }\end{array}$ & $L^{*}$ & ${ }^{*}$ & \begin{tabular}{|l} 
MR Credit 6 - Rapidly \\
Renewable Materials \\
MR Credit 7 - Certified Wood
\end{tabular} & 2 & $15 \%$ \\
\hline $\begin{array}{l}\text { Encourage the Use of Recyclable } \\
\text { Assemblies and Products }\end{array}$ & & & & $\begin{array}{l}\text { Reusability of components } \\
\text { and materials }\end{array}$ & 15.3 & $18 \%$ & $\begin{array}{l}\text { Design for disassembly, } \\
\text { reuse or recycling }\end{array}$ & & $\begin{array}{l}\text { E.4 Building durability, } \\
\text { adaptability and disassembly }\end{array}$ & 12 & $12 \%$ & & & \\
\hline Limit Construction Debris & & & & & & & & & $\begin{array}{l}\text { E.5 Reduction, re-use and } \\
\text { recycling of waste. }\end{array}$ & 10 & $10 \%$ & $\begin{array}{l}\text { MR Credit } 2 \text { - Construction } \\
\text { Waste Management }\end{array}$ & 2 & $15 \%$ \\
\hline $\begin{array}{l}\text { Eliminate the Use of Materials that } \\
\text { Pollute or are Toxic During Their } \\
\text { Manufacture, Use, or Reuse }\end{array}$ & $\begin{array}{l}\text { No asbestos used or } \\
\text { remains in the structure. }\end{array}$ & 8 & $8 \%$ & $\begin{array}{l}\text { Materials with low health } \\
\text { risk. Avoidance of CFCs } \\
\text { and Halons }\end{array}$ & 22.1 & $26 \%$ & & & $\begin{array}{l}\text { E.1 Low impact systems and } \\
\text { materials }\end{array}$ & * & * & & & \\
\hline \begin{tabular}{|l} 
Give Preference to Locally \\
Produced Materials with Low \\
Embodied Energy Content \\
\end{tabular} & & & & & & & $\begin{array}{l}\text { Planned use of materials } \\
\text { that are locally produced }\end{array}$ & & $\begin{array}{l}\text { E.2 Minimal consumption of } \\
\text { resources }\end{array}$ & & * & \begin{tabular}{|l} 
MR Credit 5 - Local/Regional \\
Materials
\end{tabular} & 2 & $15 \%$ \\
\hline Not Specified & $\begin{array}{l}\text { Install carpets/floor finishes } \\
\text { that are specified by the new } \\
\text { tenants. }\end{array}$ & 8 & $8 \%$ & & & & & & & & & $\begin{array}{l}\text { MR Prerequisite } 1 \text { - Storage \& } \\
\text { Collection of Recyclables }\end{array}$ & & \\
\hline Not Specified & \begin{tabular}{|l|} 
Major building elements \\
evaluation against Green \\
Guide specifications or \\
Ecopoints benchmarks. \\
\end{tabular} & 32 & $33 \%$ & & & & & & & & & & & \\
\hline Not Specified & $\begin{array}{l}\text { A central dedicated storage } \\
\text { space for recyclable } \\
\text { materials is located within } \\
\text { the building or on site. }\end{array}$ & 8 & $8 \%$ & & & & & & & & & & & \\
\hline
\end{tabular}

